\title{
The Classic Age of the Distinction between God's Absolute and Ordered Power: In, Around, and After the Pontificate of John XXII (1316-1334)
}

In more general terms, many mediaeval authors-and not only theologians-used the distinction between God's ordered and absolute power (potentia Dei absoluta and ordinata) to emphasize how, on the one hand, in an 'orderly' way, the realm of nature reflects God's freedom of choice, leading to the existence of a radically contingent order of creation; but also how, on the other hand, in terms of divine absoluteness and in the economy of salvation, God is never bound in his action, which is truly inscrutable and lies above morality. ${ }^{1}$ The extensive scholarship on this distinction clearly demonstrates how such a question represented a real 'problem' for mediaeval thinkers rather than just a simple theory. ${ }^{2}$ I am

\footnotetext{
${ }^{1}$ Francis Oakley, The Western Church in the Later Middle Ages (Ithaca, NY: Cornell University Press, 1979), 145.

${ }^{2}$ For the definition of the question of God's power in these terms, see Randi's Il sovrano e l'orologiaio. Due immagini di Dio nel dibattito sulla potentia absoluta fra XIII e XIV secolo (Florence: La Nuova Italia, 1987), 123. On the distinction between potentia Dei absoluta and ordinata, see the recent Anton Schütz and Massimiliano Traversino (eds.), The Theology of potentia Dei and the History of European Normativity European Normativity/Alle origini dell'idea di normativismo. Il problema della potentia Dei tra teologia e diritto pubblico europeo, 2 vols, Divus Thomas, 115, no. 2 (May./Aug. 2012) and 116, no. 3 (Sept./Dec. 2013). The third volume is currently under publication in Massimiliano Traversino Di Cristo (ed.), 'Sit pro ratione voluntas': L'âge moderne de la norme et la métaphysique de la volonté (Paris: Cerf, forthcoming 2018). The distinction has been the subject of much scholarly attention, mainly in light of late-mediaeval thought. In the abundant scholarship devoted to the question, see: Amos Funkenstein, Theology and the Scientific Imagination from the Middle Ages to the Seventeenth Century (Princeton, NJ: Princeton University Press, 1986), 124-52; Francis Oakley, Omnipotence, Covenant and Order: An Excursion in the History of Ideas from Abelard to Leibniz (Ithaca, NY: Cornell University Press, 1984); William J. Courtenay, Covenant and Causality in Medieval Thought: Studies in Philosophy, Theology and Economic Practice (London: Variorum Reprints, 1984); Id., Capacity and Volition: A History of the Distinction of Absolute and Ordained Power (Bergamo: Lubrina, 1990); Angela Vattese (ed.), Sopra la volta del mondo. Onnipotenza e potenza assoluta di Dio tra Medioevo e Età moderna (Bergamo: Lubrina, 1986); Guido Canziani, Miguel Ángel Granada, and Yves Charles Zarka (eds), Potentia Dei. L'onnipotenza divina nel pensiero dei secoli XVI e XVII (Milan: Franco Angeli, 2000); Massimiliano Traversino, Diritto e teologia alle soglie dell'età moderna. Il problema della
} 
limited to mentioning here that the doctrine of God's power comes to the fore with a much different significance in various historical epochs. A first example can be seen in the twelfth century through the theological and cosmological debate between the two positions represented by Peter Abelard $(\dagger 1142)$ and Peter Lombard $(\dagger 1160)$, which can be traced back to the origin of the distinction (at least with reference to the late-mediaeval discussion of this issue and not to the general history of religion). This debate asked for nothing but to clarify the limits of God's action, considering that God was viewed as an infinitely good being per se and that the natural world he created should be considered the best he could ever create. ${ }^{3}$ The original dialectic of the distinction between two separate types of God's power might be best represented by the following questions. Could God, at the time of creation (when he explicated an 'ordered' power), give rise to an order different from the one he actually created (through his absolute and free power)? And could he still create a different one? A century and a half after this debate, John Duns Scotus $(\dagger 1308)$ eventually confirmed the opinion of Peter Lombard and provided a positive answer to both of these questions. ${ }^{4}$ However, beyond the apparent similarity in content between the theories enunciated and the claims made, the terms of the discussion greatly diverged from time to time, in terms of both meaning and dynamics, and underwent a slow but steady displacement from the territory of theology to that of legal-political analysis. The legal-political usage of the distinction between God's

potentia Dei absoluta in Giordano Bruno, with a preface by Diego Quaglioni (Naples: Editoriale Scientifica, 2015).

${ }^{3}$ As to Peter Abelard, consider, for example, his Theologia 'scholarium', III. 27-9, in Id., Opera theologica, eds. Eligius M. Buytaert and Constant J. Mews, III (Turnhout: Brepols, 1987), 511-12, where Abelard rejects the question 'utrum plura facere possit Deus vel meliora quam facit ullo modo cessare posset, ne ea umquam videlicet faceret'. As to Peter Lombard, consider his Sententiae in quatuor libris distinctae, I. 43.1 and I. 43. 3 (Responsio), ed. Ignatius Brady, I, 2 (Grottaferrata: Collegio S. Bonaventura, 1971), 298-99. For an analysis of the cosmological debate between Abelard and Lombard, see Massimiliano Traversino, "Il problema della potentia Dei tra teologia e diritto canonico nei secoli XIII e XIV,” Divus Thomas 114, no. 3 (Sept./Dec. 2011): 368-85. On the intellectual impact of this debate in the later history of ideas, with special attention to Giordano Bruno, see Traversino, Diritto e teologia alle soglie dell'età moderna, esp. 71-80.

${ }^{4}$ See John Duns Scotus, Ordinatio I, dist. 44, in Id., Opera Omnia, eds. Carolus Balić and others, vi (Ordinatio I, dists 26-48) (Vatican City: Typis Polyglottis Vaticanis, 1963), $363 \mathrm{ff}$. However, it is worth mentioning that Scotus is not saying that God acts by absolute power; see La puissance et son ombre: de Pierre Lombard à Luther, ed. Olivier Boulnois (Paris: Aubier, 1994), 57, 279 ff.; Anton Schütz, "A Quandary Concerning Immanence," Law and Critique 22, no. 2 (July 2011): 189-203 (202); Anton Schütz and Massimiliano Traversino, "Foreword," in Iid. (eds.), The Theology of potentia Dei and the History of European Normativity (= Divus Thomas 115, no. 2), 13-32 (21). 
absolute and ordered power was attested already in the thirteenth century, following a theoretical trend inaugurated by Henricus de Segusio, better known as Hostiensis $(\dagger 1271) .{ }^{5}$ Such a usage will affect the history of legal theories up to the sixteenth century and beyond: from the notion of sovereignty to that of the prince, and to the question of which was the best form of government of a state and of the role, with respect to the prince, of the people and the magistrates.

In this paper, I shall inquire into the story of this distinction between the thirteenth and fourteenth century - a period in which the distinction between God's absolute and ordered power became so common, in law as well as theology, that we could almost call this period the 'classic age' of this distinction. This period saw the emergence of orientations that would prove decisive for the fate of modernity and the later history of the distinction between God's absolute and ordered power. In the pages that follow, I will try to explain the reasons, both historical and doctrinal, for the success of this latter as a specifically legal distinction during this

${ }^{5}$ For an account on Hostiensis's relevance in this context and, in more general terms, in the context of late-mediaeval legal theories, see Kenneth Pennington, "Law, Legislative Authority, and Theories of Government, 1150-1300" in James H. Burns (ed.), The Cambridge History of Medieval Political Thought, c.350-c.1450 (Cambridge: Cambridge University Press, 1991), 424-53; Kenneth Pennington, The Prince and the Law, 12001600: Sovereignty and Rights in the Western Legal Tradition (Berkeley, CA: University of California Press, 1993), esp. 38-75; Id., Pope and Bishops: The Papal Monarchy in the Twelfth and Thirteenth Centuries (Philadelphia, PA: University of Pennsylvania Press, 1984), 63-74; Id., "Enrico da Susa, detto l'Ostiense (Hostiensis, Henricus de Segusio o Segusia)," in Dizionario biografico degli italiani, XLII (Rome: Istituto della Enciclopedia Italiana, 1993), 758-63, with its English version "Henricus de Segusio (Hostiensis)," in Kenneth Pennington, Popes, Canonists, and Texts, 1150-1550 (Aldershot: Variorum, 1993): art. 16, 1-12. For further analysis, see also John A. Watt, "The Use of the Term plenitudo potestatis by Hostiensis," in Stephan Kuttner and J. Joseph Ryan (eds.), Proceedings of the Second International Congress of Medieval Canon Law: Boston College, 12-16 August 1963 (Vatican City: S. Congregatio de seminariis et studiorum universitatibus, 1965), 161-87; John A. Watt, "Hostiensis on Per venerabilem: The Role of the College of Cardinals," in Brian Tierney and Peter Linehan (eds.), Authority and Power: Studies on Medieval Law and Government Presented to Walter Ullmann on His Seventieth Birthday (Cambridge: Cambridge University Press, 1980), 99-113; Pio Fedele, "Primato Pontificio ed episcopato con particolare riferimento alla dottrina dell'Ostiense," Studia Gratiana 14 (1967): 349-67; Clarence Gallagher, Canon Law and the Community: The Role of Law in the Church according to the 'Summa aurea' of Cardinal Hostiensis (Rome: Università Gregoriana, 1978); Il Cardinale Ostiense: Atti del convegno internazionale di studi su Enrico da Susa detto il Cardinale Ostiense (Susa, 30 settembre - Embrun, 1 ottobre 1972), special issue Segusiusm 16 (1980); Uta-Renate Blumenthal, "Liber Extra 5.6.17 (Ad Liberandam): A Surprising Commentary by Hostiensis," in Paola Maffei and Gian Maria Varanini (eds.), 'Honos alit artes': Studi per il settantesimo compleanno di Mario Ascheri. 1, La formazione del diritto comune: giuristi e diritti in Europa (secoli XII-XVIII) (Firenze: Firenze University Press, 2014), 309-18. 
key period. I shall dwell, in particular, on the years from 1316 to the 1330s, under John XXII's pontificate, explaining the relevant religious and political issues of those times. To this end, I will examine the perspective of John XXII himself in relation to his two great doctrinal rivals, Meister Eckhart (†c.1328) and William of Ockham (†1347), and pay special attention to the dispute between the pope and the Franciscans over evangelical poverty

\section{The Role of Faith in the Historical and Philosophical Narrative of the Fourteenth Century}

One important point of comparison lies in the significance attributed to God's unity and simplicity. Scholastic theologians had already maintained that no attributes can be distinguished in God. For Ockham, this point was a keystone in the task of building up a metaphysics of the absolute. The entire framework of divine voluntarism, as Ockham conceived it, even when he was dealing with the theological divide between God's absolute and ordered power, is based on God's unity and simplicity from which no divine attribute can be separated out. As Ockham phrased it:

This distinction should not be understood to mean that in God there are really two powers, one of which is ordered and the other of which is absolute. For, with respect to things outside himself there is in God a single power, which in every way is God himself. ${ }^{6}$

Yet, as we shall see in the following pages, Ockham's investigation into God's power-through the interrelated discourse on papal power-has important legal implications. With respect to Eckhart, on the other hand, the acknowledgement of God's unity and simplicity leads to a rather different result. Through assertions that anticipate those of Luther's appraisal in his The Freedom of a Christian, Eckhart refers to the unicity and simplicity of God and places him at the top of a path of purification of the soul. At the end of this process, human nature is so renewed that man acquires, through a twofold and reciprocal rebirth, a power to be exercised over God: man is reborn into God, thereby becoming himself causa prima; God is reborn into man, in his quality as the Son, within the depths of the soul. Before venturing into a closer examination, I will

${ }^{6}$ William of Ockham, Quodlibet VI, q. 1, in Quodlibetal Questions, II (Quodlibets $V-V I I)$, trans. by Alfred J. Freddoso (New Haven, CT: Yale University Press, 1991), 491-94 (491). 
first remark that the two friars' dissenting positions both within scholasticism and with respect to the Church of their times played a decisive role in their writings (and, with respect to their trials, we can easily assume that Ockham's and Eckhart's views influenced the judges charged with deciding whether or not their teachings were to be considered orthodox in respect to Catholicism). In considering Ockham in particular, I will also pay attention to Scotus's version of the distinction concerning God's power in order to highlight the elements of continuity between their respective positions that are relevant to the present study.

In portraying the fourteenth century, if not the entire range of centuries of mediaeval-modern oscillation, a mere conceptual or descriptive re-creation of the facts of the past is not sufficient to grasp the epoch's specific wisdom. Purely historical or philosophical narratives seldom capture the mental habits in which history reveals itself_-or, one might add, often fails to do. In this case, the most basic condition governing any movement within the systems of thought of the time is that they were perceived as founded on, and instrumental to, faith. If and when faith and knowledge came into conflict with one another, a mediaeval theologian would never change the first in favour of the second: faith was the only locus of truth that must never be renounced. It was firmly and widely believed that the theologian's arguments should only strengthen faith and never threaten to subject it to crisis. In this respect, there was no difference between the common man and the great thinker. Once they took their vows, religious men just as much as the laity, whether within a secular order or the regular hierarchy, fully and repeatedly submitted to the authority of Scripture, which they never cast into doubt. But what if something new occurred on the side of faith itself, a newness that would only later be recognized as the seed of a criticism in the vanguard of change? An alteration-even if unconscious - in the value attached to religion in the everyday life of that epoch? Those in the fourteenth century credited with the changes that established that other change had no wish to put their system of belief to the test. In this they greatly differed from the reformers of the sixteenth century, even though these latter had their roots in the theories of the fourteenth-century masters. Religious men were individuals who contributed in a personal way to building up and uncovering the content of faith for the greater glory of the Church of God. Such subjectivism, however, never became conscious criticism of a system of thought that was considered ultimately indisputable (based as it was on tradition) and on which all of them adopted a truly conservative stand. On the other hand, it is also true that a new religious sensitivity was slowly coming into being, as can be seen in retrospect 
through the fact that it became standard for later reformers and modern thinkers to refer elements of their doctrines back to fourteenth-century authors. Those authors themselves, despite ceaseless efforts to preserve the traditional ties of religion, were unable to halt the changes already at work, even though their theories were intended to resist such changes. Their teachings, traditionalist and conservative though they were, contained within them a dangerous attack on the old scholasticism, which was slowly but inevitably crumbling. That process was, no doubt, aided by the long-standing and unrelenting struggle between the two great universal powers of empire and papacy that had until then sustained society and its cultural habits. This was a crisis the fourteenth-century writers appeared unable to withstand. Also contributing to this erosion was the call, invoking a 'blend' of temporal and spiritual authorities, for a return to the primitive purity of a Christianity uncontaminated by vices and the mundane corruption of secular society. It is within this milieu-in the harsh living conditions of the 1320-30s - that the Franciscan Order demanded that the Church condemn clerical abuses and renounce temporal ambitions. This marked the revival of an earlier, pacified but still latent, internal criticism, to which was now added more recent criticisms by people belonging to unofficial orders.

The important role of unofficial religious life typical of the first decades of the fourteenth century is a crucial element in the mix of circumstances considered here. Religious communities of 'difficult' institutional identification had long since sprung up, especially in Germany and southern France, within or close to regions under Franciscan and Dominican control. Indeed, the decree Religionum diversitatem nimiam issued by the Second Council of Lyon in 1274 pronounced a general prohibition on the constitution of new orders. Yet such groups continued to proliferate at will, with their followers pursuing their ideals of religious life outside the official forms of congregation. In their view, it seems, the divisions of the official orders within both their own and ecclesiastical hierarchies betrayed the original spiritual message on which they had been constituted. The number of these 'unofficial' associations increased at an extraordinary rate in the late thirteenth and early fourteenth centuries, with members acting as if these were approved orders-for example, by publicly begging from the faithful. Some held seemingly heretical views about the sacraments, representing a clear challenge to the Holy See. As a consequence, in 1317, Pope John XXII eventually excommunicated these associations and stopped their proliferation. ${ }^{7}$ The internal division within

${ }^{7}$ Sancta Romana, 30 December 1317, in Extravagantes Ioannis XXII (1325), tit. VII, De religiosis domibus, cap. un., in Corpus iuris canonici. Editio lipsiensis secunda, eds. Ae- 
the Franciscans over the doctrine of the usus pauper as well as the subsequent doctrinal interventions of John XXII echoed the concerns of the 'unofficial' religious associations about ecclesiastical hierarchies, incorporating the theme of the betrayal of the original spiritual basis of their constitution. ${ }^{8}$ With this shift in the confrontation from doctrinal dispute to obedience, the papacy could no longer avoid taking action, which in turn forced its opponents, firmly on the side of the evangelical virtues, to search for answers beyond the institutional Church, mired as it was in worldly matters and corruption. The definitive break between the pope and the Franciscan Minister General Michael Fuschi of Cesena (†1342) came in 1328. This had an immediate political significance when the latter and his dissident group, which included the luminaries William of Ockham and Bonagratia of Bergamo ( $† 1340)$, fled Avignon and joined Louis IV of Bavaria ( $† 1347)$, who held imperial power but, contrary to hitherto established practice, without papal approbation. With respect to such questions, Meister Eckhart's and William of Ockham's writings and their trials appear to contain the whole theory and drama.

milius Ludwig Richter and Emil Albert Friedberg, 2 vols (Leipzig: Tauchnitz, 187981), II (1881), cols 1213-14; see Appendix, 1.

${ }^{8}$ A classic study on the question of poverty and its relevance in the fourteenth century is Felice Tocco, La questione della povertà nel secolo XIV secondo nuovi documenti (Naples: Perrella, 1910). For a comprehensive account of these debates, see Malcom D. Lambert, "The Franciscan Crisis under John XXII," Franciscan Studies 32 (1972): 123-43; Id., Franciscan Poverty: The Doctrine of the Absolute Poverty of Christ and the Apostles in the Franciscan Order, 1210-1323, 2nd rev. ed. (St Bonaventure, NY: Franciscan Institute Publications, 1998, 1961); Paolo Grossi, "Usus facti. La nozione di proprietà nella inaugurazione dell'età nuova,” Quaderni fiorentini 1 (1972): 287-355; Edith Pásztor, "Le polemiche sulla Lettura super Apocalipsim di Pietro di Giovanni Olivi fino alla sua condanna," Bullettino dell'Istituto storico italiano per il medio evo e Archivio muratoriano 70 (1958): 365-424; David Burr, "The Persecution of Peter Olivi," Transaction of the American Philosophical Society 66 (1976): 1-98; Id., The Spiritual Franciscans: From Protest to Persecution in the Century after Saint Francis (University Park, PA: Pennsylvania State University Press, 2001); Peter John Olivi, De usu paupere: The Quaestio and the Tractatus, ed. David Burr (Florence: Olschki and Perth: University of Western Australia Press, 1992), 3-85; Thomas Turley, "John XXII and the Franciscans: A Reappraisal," in Popes, Teachers and Canon Law in the Middle Ages, eds. James R. Sweeney, and Stanley Chodorow (Ithaca, NY: Cornell University Press, 1989), 74-88. A more general perspective on the role the question of poverty played in the whole of the mediaeval history of the Order is taken by Duncan Nimmo, Reform and Division in the Medieval Franciscan Order: From Saint Francis to the Foundation of the Capuchins, 2nd ed. (Rome: Capuchin Historical Institute, 1995). 


\section{Avignon, the Temporal Role of the Church—and John XXII}

It should not be forgotten that the conflict between papacy and empire in the first half of the fourteenth century was the final chapter in a long and mostly uninterrupted history of pontifical-imperial tensions dating back to the late eleventh century. ${ }^{9}$ The papal court at Avignon was the subject of vast criticism, in which old issues concerning the overworldly character of the Church were now themed on the protracted absence of the popes from their original Roman seat. Such criticism was expressed not only within the Church by spiritual leaders like Bridget of Sweden $(\dagger 1373)$ and Catherine of Siena ( $† 1380)$, but also by critics such as the poets Dante $(\dagger 1321)$ and Petrarch (†1374). However, it was during this period of 'Babylonian captivity' that the government of the Church achieved the progressive centralization that later made it possible for the papacy to establish a modern administrative and financial system. ${ }^{10}$

Regarding John XXII himself-despite the opprobrium attached to the Avignon popes in general and his own customary image as the Franciscans' foe in the scholarship about the poverty controversy in the 1320-30s - perhaps it is time for a careful re-examination of the traditional appraisal. From an external perspective, one sees, for example, that the Franciscans' internal debates on the correct interpretation of poverty had already developed into an open division, which 'was threatening to nullify', as Duncan Nimmo phrases it, 'all the good the Order had done and yet could do'. This situation 'was proving a misery both to [the Franciscans] and to the Church', so that it is perhaps legitimate to say, with respect to the later steps he would take, that John XXII 'ascended the papal throne determined [...] to save the Order from itself, and renew its usefulness, by suppressing the dissensions once and for all, and restoring its unity'. ${ }^{11}$

Certainly, compared with his immediate predecessor, Clement V $(\dagger 1314)$, John was held, in his time and by today's scholars, in much higher regard. Much has been said about John's physical, moral, and intellectual strength; his impressive career, starting late in his life, can indeed

\footnotetext{
${ }^{9}$ See in particular: Hilary S. Offler, "Empire and Papacy: The Last Struggle," Transactions of the Royal Historical Society, Series V, 6 (1956), 21-47, repr. in Id., Church and Crown in the Fourteenth Century: Studies in European History and Political Thought, ed. Anthony I. Doyle, II (Aldershot: Ashgate, 2000), 21-47; Brian Tierney, The Crisis of Church and State, 1050-1300, 2nd rev. ed. (Toronto, ON: University of Toronto Press, 1988).

${ }^{10}$ Bernard Guillemain, Les papes d'Avignon, 1309-1376 (Paris: Cerf, 1998), 137-38.

${ }^{11}$ This and the preceding quotation are taken from Nimmo, Reform and Division, 134.
} 
hardly be understood otherwise. ${ }^{12}$ When he was elected to the Holy See in 1316, James II King of Aragon and Valencia's correspondent described the prevailing response (in Lyon), stating that John 'would avoid simony, with respect to both himself and others, be parsimonious in granting favours and graces and strictly fair'. ${ }^{13}$ The correspondent said also that it was feared that the pope would not be 'overly confident in his own wisdom'. Painted in these colors, Jacques Duèze, former bishop of Avignon and now Pope John XXII, does not resemble his customary image as denounced so resoundingly, for example, by Dante. ${ }^{14}$ Even Petrarch, whose general judgement on the Avignonese papacy is well known, described John XXII as a man who was a hard worker, had a vehement soul, and, although fervently willing to read books, was nonetheless so devoted to his role that he engaged himself in intractable disputes with the emperor and his court, a task to which he seems to have dedicated half of his life. Confronting the problems of his age and the great number of institutional duties that consumed his time and prevented him from reading, John XXII was, as Petrarch phrases it, sincerely grateful to anyone who provided him with the summary of a book, which enabled him to gain knowledge of the substance and content. ${ }^{15}$ This portrait conveys something of the constant attention to governmental-temporal-tasks required in the huge effort of building up a strong, centralized, and monarchical Church undertaken by the pope (as well as an entire series of Avignonese pontiffs in his wake). Consequently, John's practical agenda for religious reform inevitably had an indisputable political significance. Indeed, it is rather difficult, today, to distinguish the realms of the political or temporal from the religious, strictly speaking. This applies equally to the numerous anti-heresy investigations that he instigated even before the inquisitorial tribunals in Avignon and to the question of poverty over which he confronted the Franciscan Order. But now I will turn to take a closer look at this latter topic.

${ }^{12}$ Bernard Guillemain, La cour pontificale d'Avignon, 1309-76: Étude d'une société (Paris: De Boccard, 1962), 130. See also Lambert, Franciscan Poverty, 240-42, and Raoul Manselli, "Un papa in un'età di contraddizione: Giovanni XXII," Studi romani 22 (1974): 444-56.

${ }^{13}$ ' [...] pour lui et pour les autres, le nouvel élu évitera la simonie, il sera parcimonieux dans la concession des faveurs et des grâces et rigoureusement juste. On craint même qu'il ne soit trop confiant dans sa propre sagesse.' Heinrich Finke, Aus den Tagen Bonifaz VIII: Funde und Forschungen (Münster: Aschendorff, 1902), LXVII-LXVIII, as quoted by Guillemain, La cour pontificale d'Avignon, 130.

${ }^{14}$ For example, Dante, Par. xvin. 130-36; see Appendix, 2.

${ }^{15}$ Petrarch, Rerum memorandarum libri quattuor, critical ed. Giuseppe Billanovich (Florence: Sansoni, 1945): II, 91 (Moderna), 1-2; see Appendix, 3, and cf. Guillemain, La cour pontificale d'Avignon, 132 and n. 181. 


\section{The Question of Poverty in the 1320-30s}

When, in 1328, the group led by Michael of Cesena finally rebelled against John XXII on the question of evangelical poverty and took shelter under the mantle of Louis of Bavaria, they were endorsing an opinion that had been common to a dissenting part of the Franciscan Order for an extended period. ${ }^{16}$ During the second half of the thirteenth century, the very first controversies, never definitively overcome, about the interpretation of the doctrine of usus pauper gave rise to the division between Conventual and Spiritual friars. This conflict anticipated in many respects the successive internal debates of the first decades of the fourteenth century as well as the polemics targeting the papacy. The Conventuals maintained that the essence of poverty consisted in renouncing all legal rights to any property whatever, both individually and in common. The Spirituals, on the other hand, affirmed that not merely the abandonment of legal rights but also a rigorous practice of poverty (usus pauper) was necessary. ${ }^{17}$ The Franciscan doctrine of poverty was the foundation upon which the Order established itself. But interpreting this doctrine proved insidiously difficult.

\section{Before the 1320-30s Debate: The Doctrine of Poverty According to Bonaventure and Olivi}

First and foremost, Bonaventure, in his Apologia pauperum contra calumniatorem, provided the official Franciscan version of evangelical poverty. ${ }^{18}$ According to Bonaventure, as found in the Gospel and explained by the Rule, the absolute evangelical poverty of Christ and the apostles consisted of a twofold lack of ownership, individual and communal at the same time. Bonaventure arrived at this conclusion by studying many scriptural and patristic references: concluding that such an absolute notion of poverty must coincide with the Franciscan way of life because, in his opinion, it was the evangelical way of life that Francis had in mind when he laid down the Rule. Absolute poverty was, in other words, intended as the only viable way of life inside the Order, to which every friar had to conform in order to truly emulate Christ and the apostles.

${ }^{16}$ Lambert, Franciscan Poverty, 263.

17 "Question de J. Olivi, Quid ponat ius vel dominium ou encore De signis voluntariis," ed. Ferdinand Delorme, Antonianum 20 (1945): 309-30.

${ }^{18}$ Bonaventure of Bagnoregio, Apologia pauperum contra calumniatorem, in Id., $O p$ era omnia, ed. Bernardino da Porto Romatino, viii (Florence: Quaracchi, 1898), 30-330. 
Along with Bonaventure, Peter John Olivi was also to play an important role in the debate on the doctrine of poverty. His writings had already influenced the first controversies in the last decades of the thirteenth century; but in light of the dramatic turn that these divisions took under John XXII's pontificate, they gained an even greater critical value, chiefly in the matter of heresy. Olivi was regarded as a saint by the Spiritual friars. He was the author of the Lectura super Apocalypsim and the doctrine of two churches. The first of these was the 'carnal' church, constituted by the unworthy and corrupt among both the laity and the ecclesiastical hierarchy, whether or not following a particular rule. The second was the 'spiritual' church consisting of those who, following a strict regime of imitating the poverty of Christ and the apostles, remained poor and pure. The duty of the latter was to resist their carnal counterpart as long as the government of that carnal and worldly church lay in the hands of an antichrist. Olivi seems to envisage this antichrist as a usurper of Peter's see, a false pope or antipope, enthroned at the top of a temporal hierarchy of power. The spiritual church would have to wage a war-a war that was bound to be finally victorious, giving a new lease of life to the Church of God. ${ }^{19}$

By appealing to such authorities, the Spirituals considered themselves to be adhering to the only legitimate action, remaining faithful to an uncompromising minority that firmly defended genuine Catholic faith when almost the entire body of the Church had effectively abandoned it. During the ensuing religious war avant la lettre of the 1320s, the pope and Michael and his group gradually, through continuing escalation, pushed their antagonism to the point of irreconcilability. At this point, Michael and his followers chose to go into exile rather than submit to John XXII, seeing themselves as defendors of the true Church against a heretical pseudo-pope. While this scenario had in a sense been foreseen by Olivi decades earlier, what made the conflict so intractable, and Michael and his group so unwilling to make concessions, was that they identified themselves not with the exponents of the radical, spiritual Franciscan group, but with the Conventuals. ${ }^{20}$ What, then, led to the dramatic turn of events in 1328? A brief review of the salient moments will help to answer the question.

\footnotetext{
${ }^{19}$ On these questions, see the scholarship mentioned in note 8 above.

${ }^{20}$ On this point, see, for example, Tierney, Origins of Papal Infallibility, 210, and Lambert, Franciscan Poverty, 267.
} 


\section{Chronology of the Events Leading Up to the 1320-30s Outbreak of the Question}

When the Franciscan General Chapter held in Naples in 1316 appointed Michael of Cesena as Minister General, the first major problem the new leader faced was the Order's Conventual-Spiritual conflict. Michael, a Conventual, had attempted to maintain a neutral position in managing this internal conflict. For his part, John XXII, never hesitant in expressing hostility toward the Spirituals, who were critical of the papacy, inflicted a severe blow on them in October 1317 with the bull Quorundam exigit. Poverty, the pope held, was certainly a great and important task, but the integrity of the body of the Church was even higher. Hence obedience to the pope ought to be considered the greatest good. ${ }^{21}$ In view of the growing crisis with the pontiff, Michael called for the Spiritual friars to show obedience to the papacy, feeling that this was the only way to contain the growing rift and put a stop to the ensuing disorder. In spite of this initial tendency, an extended sequence of dramatic incidents and cases of insubordination to the pope's authority ensued, including the trial of twenty-five Spirituals. This concluded on 7 May 1318 in Marseilles with the burning at the stake as heretics of four friars who adamantly refused to submit themselves to the papal authority. ${ }^{22}$ One should not forget that Quorundam exigit had a purpose that was chiefly administrative, aiming to reduce the Spirituals to obedience. ${ }^{23}$ Only later, in the bull Sancta Romana, issued three months after Quorundam exigit, did the pope 'shift his interest from discipline to doctrine' ${ }^{24}$

At this point, I shall examine the narrative of the Chronicle of Nicholas the Minorite, a document that has been the starting point for much of the historiography on the question of poverty. ${ }^{25}$ It opens with the dis-

${ }^{21}$ See Lambert, Franciscan Poverty, 227, and Takashi Shogimen, Ockham and Political Discourse in the Late Middle Ages (Cambridge: Cambridge University Press, 2007), 39, both with explicit reference to the text of Quorundam exigit.

${ }^{22}$ For a narrative of the event, see Lambert, Franciscan Poverty, 228. See also: Manselli, "Un papa in un'età di contraddizione," 453; David Burr, Olivi and Franciscan Poverty: The Origins of the 'Usus Pauper' Controversy (Philadelphia: University of Pennsylvania Press, 1989), ix; Virpi Mäkinen, Property Rights in the Late Medieval Discussion on Franciscan Poverty (Leuven: Peeters, 2001), 146. On the friars' condemnation as heretics, see also Gratien Badin, Histoire de la fondation et de l'évolution de l'Ordre des frères mineurs au XIII siècle (Paris: S. François d'Assise, 1928), 494 and n. 34.

${ }^{23}$ Shogimen, Ockham and Political Discourse, 39-49 (39).

${ }^{24}$ Ibid. On this shift, Lambert, Franciscan Poverty, 230, notes that Sancta Romana is extremely "significant [...] for the insight it gives into the state of John XXII's thought at this time."

${ }^{25}$ For the Chronicle, see Nicolaus Minorita: Chronica. Documentation on Pope John XXII, Michael of Cesena and The Poverty of Christ with Summaries in English. A Source 
pute between the pope and the Friars Minor renewed after a new case in Narbonne in 1321 involving the interpretation of poverty. The case arose following the imprisonment of a Beguin, who was himself defending the thesis of the individual and communal absolute poverty of Christ and the apostles, at the demand of the local Archbishop Bernard de Fargis and of the Dominican Inquisitor John of Belna. In the examination by the advisory court the Inquisitor invested with the case, one of its members, Bérenger Talon, a lecturer at the local Franciscan convent, sided with the Beguin. He affirmed that the proposition that Christ and the apostles owned nothing either personally or in common had been officially accepted by the Church since time immemorial, ratified by Pope Nicholas III ( $† 1280)$ in his bull Exiit qui seminat of 1279 and never since rejected. Talon's position openly opposed that of John of Belna. According the Chronicle, John asked Talon to recant and he did not. Since the contrast was finally irreconcilable, Talon, who feared the consequences of his opposing the Inquisitor, appealed to John XXII in Avignon and led the question of Christ and the apostles' poverty to further discussion. ${ }^{26}$ While this new inquiry focused particularly on Olivi's teaching as expounded in his Lectura super Apocalypsim, it also determined to more closely investigate, and consequently to question, the whole of the Franciscan doctrine on poverty, including the identification it encouraged between the Franciscan Rule and the Gospel. The effect of this was to supply the already-volatile Franciscans with more, highly explosive, ammunition and to bring the discussion to a point of no return. ${ }^{27}$

What is required here is a careful examination of the texts. Over the past thirty years, many writers have relied heavily upon the narrative offered by the Chronicle of Nicholas the Minorite. The conviction

Book, eds. Gedeon Gál and David Flood (St Bonaventure, NY: The Franciscan Institute Publications, 1996), also reporting all the relevant papal constitutions and Franciscan declarations concerning the dispute. For the opening of the Chronicle, see ibid., 62-63 Among the many studies that rely on the narrative of this source, including its opening, see, for example, Lambert, Franciscan Poverty, 239-40. In contrast with this scholarship and in favour of a thorough reconsideration of the narrative of the Chronicle, see Patrick Nold, Pope John XXII and His Franciscan Cardinal: Bertrand de la Tour and the Apostolic Poverty Controversy (Oxford: Clarendon Press, 2003); Nold considers the Chronicle untrustworthy because it depends on the position of those Franciscans opposing John XXII.

${ }^{26}$ For a recent account of the narrative of Talon's appeal and of John's decision to reopen the case, see Mäkinen, Property Rights, 143-44.

${ }^{27}$ Concerning a Dominican influence on the course of action enacted by the pope in this situation, see esp. Turley, "John XXII and the Franciscans: A Reappraisal," and, more recently, Shogimen, Ockham and Political Discourse, 40. Still on the Dominican influence on papal views, a classic interpretation is Franz Ehrle, "Die Spiritualen, ihr Verhältnis zum Franziskanerorden und zu den Fraticellen," Archiv für Literatur- und Kirchengeschichte des Mittelalters 4 (1888): 1-190 (45-50). 
that John XXII revoked the bull Exiit qui seminat of Nicholas III, the document that had officially approved the Franciscan way of life, has especially been taken at face value. Yet a closer inspection of both the texts and the context reveals we need to reconsider such a position. In short, according to the Chronicle, John XXII's Quia nonnunquam of 26 March 1322 declared the doctrine stated by Exiit qui seminat null and void, an assumption based on the opening sentences of the document: 'it must not be considered reprehensible if the law-maker is striving to revoke, change or suspend canons that he himself or his predecessors promulgated, if he sees them to be more detrimental than helpful. ${ }^{28}$ According to the Chronicle, the pope's action is based on his goals with respect to the debate with the Franciscans over Christ's poverty: in his capacity as a trained canonist, the pope seemed to defend the fallibility of papal statements in taking a stand and finally resolving the controversy. This resulted—still according to the Chronicle-in John XXII's resolution to reform the decisions made by his predecessor Nicholas III, regardless of the number of authoritative positions defending the counter-principle of papal infallibility. ${ }^{29}$ An unprejudiced examination of the document, however, reveals that John XXII was under pressure from divisive forces in the Church and that the radical step of condemning Olivi's doctrine was a response to these circumstances. This condemnation was impossible without rejection of its official approval by Nicholas III's decree. ${ }^{30}$ The narrative of the Chronicle notwithstanding, in no passage of his bull did John XXII explicitly revoke the Exiit. Rather, he only recognized as valid, as a matter of principle, the pope's right to proceed in exceptional cases to the extreme step of revocation, if and when he considered it to be necessary. On close inspection of the bull, though, we find that John XXII was not taking such a step. By claiming the pope's prerogative in

28 "non debet reprehensibile iudicari, si canonum conditor canones a se vel suis praedecessoribus editos, vel aliqua in eisdem contenta canonibus revocare, modificare vel suspendere studeat, si ea obesse potius viderit quam prodesse." Quia nonnumquam, 26 March 1322, in Extravagantes Ioannis XXII, tit. XIV, De verborum significatione, ch. 2, in Corpus iuris canonici, II, col. 1224.

${ }^{29}$ See Thomas Turley, "Infallibilists in the Curia of Pope John XXII," Journal of Medieval History 1 (1975): 71-101 (esp. 79-80), in reference to the Carmelite Prior General Guido Terreni's defence of papal infallibility; see also Shogimen, Ockham and Political Discourse, 40. For a contrary interpretation of John XXII's Quia nonnunquam and against the generally accepted opinion that John declared the Exiit qui seminat null and void, see by Patrick Nold, Pope John XXII and His Franciscan Cardinal, 22.

${ }^{30}$ See Joseph Koch, "Der Prozess gegen die Postille Olivis zur Apokalypse," Recherches de Théologie Ancienne et Médiévale 5 (1933) : 302-15. This position has been questioned and partially emended by more recent studies, among them chiefly the above-mentioned surveys of Burr and Lambert on the Olivi affair. 
his capacity as the head of the Church to move against a preceding status $q u o$, the bull explicitly asserted only the suspension of Nicholas's Exiit where it prohibited, under threat of excommunication, any but a literal interpretation of its own content. John XXII's decision to suspend this limited part of the Exiit was based upon the same motivations that had led Nicholas III to insert it: Nicholas wanted to rule out the possibility of ongoing interpretations or discussions that could engender doubts about the content of the Rule (which he had approved). Just like Nicholas before him, John was trying to assert control over the situation of uncertainty during the years of his own pontificate. Yet he accomplished this by initiating a discussion destined to reconcile all the parties to the conflict, which is also why he summoned a public consistory and invited lawyers and theologians to participate in it along with the friars and clergy. But John repeatedly emphasized that such a decision should not give rise to any kind of writing or debate that could harm the Franciscan Rule. Finally, the Quia nonnumquam reported that the pope ordered its text to be displayed on the door of the Cathedral of Notre-Dame des Doms, the main church of Avignon, wanting to instigate as much public interest and participation in the discussion as possible.

In the opinion of the Franciscans, however, such guarantees masked the intention of introducing into discussion a doctrine in which they saw the only legitimate interpretation of evangelical poverty, as it was inherited by Francis and had been confirmed by more than one pontiff. This explains the Franciscans' defiant reaction to John XXII's decision and, as a consequence of this reaction, the radical shift in the politics of the Holy See towards them. 'The central issue was no longer the doctrine of the Spirituals', but the wound inflicted upon the 'hearth of the Franciscan doctrine' itself, that is, the strict interpretation of Christ and his apostles' poverty. ${ }^{31}$ In addition, in that same General Chapter, the Friars Minor claimed once again that their doctrine of poverty had been left untouched by all the papal constitutions from Nicholas III's Exiit qui seminat of 1279 to Clement V's Exivi de paradiso of 1312. John XXII's Quia nonnumquam, and his decision to ignore what the Perugia General Chapter had issued, had the effect of distancing his assessment from that of his adversaries. At the same time, the situation shifted the core of the polemic from the question of poverty to that of obedience. A quick overview of the contents of the decision taken by the General Chapter of Perugia and of John XXII's reactions will allow us to follow up on the issue.

${ }^{31}$ Shogimen, Ockham and Political Discourse, 41. On this shift, see Quia nonnumquam, col. 1224; see Appendix, 4. 


\section{The Debate over Poverty as a Juristic Confrontation on Papal Power}

The later course of John XXII's pontificate appears to be a genuinely doctrinaire effort to reduce the Rule to charity and collective ownership of goods, as can be easily concluded from a quick assessment at his decretals from 1322 onwards: Ad conditorem canonum, 8 December 1322; Quum inter nonnullos, 12 November 1323; Quia quorundam, 10 November 1324; and Quia vir reprobus, 16 November 1329. John XXII's dealings with the Franciscans involved the entire Franciscan doctrine of Christ's poverty, be it in Bonaventure's or Olivi's formulation. The issue at stake in the dogmatic dispute between the pope and the Friars Minor, to the extent to which it concerns the nature of papal power, also has a clear legal and political dimension. In this new light, the dispute can be perceived as a juristic debate between two competing and mutually exclusive concepts of papal power: heralding, on the part of John XXII, the sovereign power of emendation and, on the part of the Franciscans, the irreformability of the statement of John's predecessor, Nicholas III. ${ }^{32}$

The problem of the limits to papal power was indeed dramatically present at a time as critical as the 1320s, involving bitter rivalry over the theme of poverty. John XXII's Quia nonnumquam provoked further resistance from the Friars Minor: the pope did not mention them explicitly, but, by referring directly to Nicholas III's bull, he questioned the ideal of poverty as it was followed by the Franciscans. The General Chapter of Perugia of June 1322 was quick to reply to John's Quia nonnunquam with two encyclicals stating that all the decisions of the Roman Church, including those preceding John's pontificate that approved the Franciscan position for an absolute poverty of Christ and the apostles, had to be considered irrevocable and, insofar as they were not heretical, could not be declared null and void. ${ }^{33}$ So, while, in Quia nonnunquam, 'John XXII had claimed', as Shogimen puts it, 'that his sovereign power allowed him to revoke the decrees of his predecessors at any time which he considered expedient', the encyclicals of Perugia took the opposite stand and de-

${ }^{32}$ Along with Tierney, Origins of Papal Infallibility, 1150-1350, see also Takashi Shogimen, "The Relationship between Theology and Canon Law: Another Context of the Political Thought in the Early Fourteenth Century," Journal of the History of Ideas 60, no. 3 (July 1999): 417-31; Id., Ockham and Political Discourse, 39-51; William D. McCready, "Papalists and Antipapalists: Aspects of the Church-State Controversy in the Late Middle Ages," Viator 6 (1975): 241-73.

${ }^{33}$ For the encyclicals, see Nicolaus Minorita: Chronica, eds. Gál and Flood: Littera capituli generalis, missa universis christifidelibus, 67-70 (in response to Pope John XXII, esp. 67-68; see Appendix, 5); Declaratio magistrorum et baccalariorum de paupertate Christi et apostolorum, 71-82. 
fended the integral 'irrevocability of papal decrees' ${ }^{34}$ On 8 December, at the request of the Franciscan procurator to the Holy See, Bonagratia of Bergamo, Pope John XXII responded with the bull Ad conditorem canonum. To facilitate discussion on the question of poverty, as had occurred in the case of the Quia nonnunquam, the pope wanted to display the text on the door of the Cathedral of Notre-Dame des Doms. ${ }^{35}$ The new document, in which the pope confirmed his preceding position, seemed to represent a sentence against his opponents. In a consistory held on 14 January 1323, Bonagratia vigorously protested against the pope and was consequently punished by being confined for one year. ${ }^{36}$

The Chronicle also reported the sophisticated argument that Michael of Cesena would later use to turn the pope's attacks upside down. Summoned before the papal court in 1327, Michael affirmed that if the approval of the Franciscan doctrine of poverty in Exiit qui seminat was to be regarded as heretical, then Nicholas III himself must be regarded as a heretic and as not having been a true pope, in which case, his deficiency would be extended to his successors who had ratified his bull and to the college of cardinals who had elected John XXII, the current pope. According to this argument, then, by condemning the Franciscan interpretation of evangelical poverty, John XXII was affirming at the same time not to be a true pope! ${ }^{37}$

This appraisal of the Chronicle's version of events-and the consideration of whether it provides sufficient material to make sense of the conflict situation as a whole-is not intended to diminish or question the polemical preoccupations of the exiled friars, nor that of the Avignonese curia. Nor is it to be understood as a comprehensive questioning of a

${ }^{34}$ Shogimen, Ockham and Political Discourse, 42.

${ }^{35}$ Bonagratia of Bergamo, had written a Tractatus de paupertate Christi et apostolorum, answering the pope's bull sometime in 1322, after the Declarationes (Littera and Declaratio magistrorum) of June and July, but before the bull of December. The first edition of Ad conditorem canonum was revised the following year; both are in Nicolaus Minorita: Chronica: I redactio, 83-88 and II redactio et longiore, 118-27, respectively, eds. Gál and Flood. The latter is published in Extravagantes Ioannis XXII, tit. XIV, De verborum significatione, ch. 3, in Corpus iuris canonici, II, cols 1225-29.

${ }^{36}$ See Mäkinen, Property Rights, 148, and Lambert, Franciscan Poverty, 252. For the text of Bonagratia's protest, see Appellatio Bonagratiae contra bullam 'Ad conditorem canonum', in concistorio Papae porrecta 14. jan. 1323, in Nicolaus Minorita: Chronica, eds. Gál and Flood, 89-117.

${ }^{37}$ See Appellatio Michaelis in Avenione, in Nicolaus Minorita: Chronica, eds. Gál and Flood, 182-89 (187); see Appendix, 6. Cf. Shogimen, Ockham and Political Discourse, 42. On the necessity of correcting the date referred to by the Minorite (13 April 1328), cf. Léon Baudry, Guillaume d'Occam. Sa vie, ses æuvres, ses idées sociales et politiques, I. L'homme et les auvres (Paris: Vrin, 1949), 114 n. 4. 
document that was compiled several years after the affair it describes. ${ }^{38}$ Yet, a more objective evaluation of the events the document refers to will oblige us, once again, to widen the context in order to better appreciate John XXII's decrees.

\section{The Bull Quia quorundam (10 November 1324) v. Bonaventure's Doctrine}

In the bull Quia quorundam, published on 10 November 1324, John XXII attempted to end the controversy with the Franciscans and argued that the claim concerning the absolute poverty of Christ and his apostles, whether individually or in common, was not consistent with the explicit teaching of the Gospel and thus could not be justified on biblical grounds. John maintained that when Nicholas issued the Exiit qui seminat he had dealt first with the three vows-living in obedience, without property, and in chastity-and then with other statements found in the Gospel, understood in light of the Franciscan Rule. This, John went on to explain, in no way contradicts what he, John, had promulgated. There was nothing to indicate, that Nicholas believed that Christ and the apostles' way of sustaining themselves was based upon use alone, nor did he even mention Christ or the apostles. Given that all he had mentioned was the renouncing of property and not any other rights, one could justifiably interpret Nicholas's position to be that Christ and the apostles had, if not a right of property, some other right to that which they were using. ${ }^{39}$ Bonaventure's doctrine, in the form in which it was defended by the Franciscans, relied upon a rather different interpretation of Scripture. The most essential element of the Franciscan position was the assumption that Christ and the apostles had neither individual nor common ownership (dominium) and use of money. Bonaventure deployed many authorities in support of Christ and the apostles having practised such an absolute poverty as their way of life. But there was an equally valid series of counter-authorities who supported the opposite view. According to them, the Gospel texts revealed that Christ and the apostles had held dominium and used money. Many adduced, in particular, a passage from the episode of the Last Supper, according to which the apostles understood Jesus's words towards Judas 'What you are going to do, do it quick-

${ }^{38}$ See Nold, Pope John XXII and his Franciscan Cardinal. For a different interpretation, see Turley, "Infallibilists in the Curia of Pope John XXII."

${ }^{39}$ Quia quorundam, 10 Novembre 1324, in Extravagantes Ioannis XXII, tit. XIV, De verborum significatione, ch. 5, in Corpus iuris canonici, II, cols 1230-36 (cols 1232-33); see Appendix, 7. 
ly' as an exhortation to Judas to 'buy what [was] needed for the supper' or to 'give something to the poor'. ${ }^{40}$ The passage clearly supported the impression that Judas was given custody of money.

Quia quorundam also denied any conflict whatever with respect to what an even earlier incumbent of the papal office, Honorius III (†c.1227), affirmed in his Solet annuere of 1223 on the occasion of investing the Regula bullata with a pontifical confirmation. In John XXII's opinion, Honorius had limited himself to reasserting what the Rule had said without any explanation, so that anyone who examined that bull attentively would immediately see it as a confirmation of the approval orally given by Honorius's immediate predecessor, Innocent III, to the primitive rule that Francis had submitted to Innocent. The only passage that mentioned the theme of evangelical life was, as John explains, one that, repeating a passage of the Rule, exhorted followers to observe the Gospel by living in obedience, without anything of one's own, and in chastity. One cannot conclude from this that Honorius had himself delivered an analogous definition, nor can it be presumed that he judged common ownership to be in contradiction with Christian perfection. Even if Honorius had been willing to assert such a thing with respect to individual ownership by repeating the passage of the Rule, this could not be construed as expressing a denial of at least communal ownership. ${ }^{41}$ However, John, in stark constrast with the image of him given by the Chronicle, does not explicitly mention either the voidness of his predecessors' decretals, in particular in relation to the Exiit qui seminat, or the issue of a possible common ownership by Christ and the apostles. On the other hand, he attempts to interpret his predecessors' statements in light of the practical programme underlying his own agenda. By so doing, once he has ascertained the total absence of any assumption relating to communal ownership, he proceeds to argue that Nicholas, in trying to rule out a potential objection to his teaching on that point, explicitly refers to the 'loculi' (money bags) that the Gospel attributes to Christ. This provides John's argument with its main objection to the notion of usus facti. ${ }^{42}$ Christ, whose works are to be regarded as perfect and whose actions were accomplished with the same perfection, sometimes complied with the imperfection typical of weak people; and, while extolling the path of perfection, he nonetheless refrained from damning the infirm ways of life of imperfect people. This is how, in John XXII's opinion, we have to understand the reference to the availability of money bags.

${ }^{40}$ John 13:27-29; for a discussion of this source with respect to Franciscan poverty, see Lambert, Franciscan Poverty, 62-72 (67).

${ }^{41}$ Quia quorundam, cols 1231-32; see Appendix, 8.

${ }^{42}$ Quia quorundam, col. 1233; see Appendix, 9. 
Christ accepted the personal character of the weak in this case precisely by making use of money. Such a usage should not be understood in terms of a simple usus facti. Christ must be the owner, at least on a communal basis, of the money bags, because otherwise the reference to the taking up of the 'weak' person by Christ would be meaningless. The interpretation is-John XXII seems to be willing to say-not new at all, as such an argument can be found already in Augustine. Indeed, the decretals of John XXII's predecessors had already referred to Augustine's words on this issue. ${ }^{43}$

It must be highlighted that in defending the unbroken line of continuity that links his own teaching to that of Nicholas III, John XXII employed a juristic language. In particular, against the Franciscans' opinion, he termed Christ's relationship with the money bags as 'proprietas'-in other words, making use of their contents as one makes use of personal belongings. John's choice to proceed in this way has to be ascribed to the two documents of Perugia issued by the Franciscans only a few months earlier. These documents, in dealing with the question of the money bags held by Judas, had resolved the problem from a truly juristic perspective, albeit with a different conclusion than the pope's. 'The emphasis' of John's opponents fell not 'on Christ's intention of charity, but on his lack of ownership. ${ }^{44}$ According to the compilers of the Perugia encyclicals, the use of money bags corresponded to the need for Christ and the apostles to purchase the goods they dispensed to poor people. However, the right Christ and the apostles had with respect to the money bags was limited to the mere use of them. ${ }^{45}$ 'And to have the use, not the ownership, as Christ and the apostles had, represents', as Shogimen puts it, 'the state of innocence, since before the Fall men did not have any ownership but enjoyed the use of every temporal good. ${ }^{46}$ It is noteworthy that such a juristic understanding of the question — shared by both the Franciscans and John XXII-is not an original invention of the fourteenth-century debate on poverty. Their arguments were based on a series of sources of the preceding century which both sides would have been familiar with. On his part, John XXII's account resorts to middle-thirteenth-century arguments held by William of Saint-Amour (†1272) and Gerard of Abbeville (†1272). These arguments not only presented Christ and the apostles' relationship with material goods in terms of ownership or pos-

${ }^{43}$ Quia quorundam, see Appendix, 10. Cf. Lambert, Franciscan Poverty, 151-52, and Shogimen, Ockham and Political Discourse, 44-46, which already presented the discussion on Judas's money bags from a legal perspective.

${ }^{44}$ Shogimen, Ockham and Political Discourse, 46.

${ }^{45}$ Ibid.

${ }^{46}$ Ibid. 
session, but also, by emphasizing consumables, rejected the Franciscans' distinction between use of goods and ownership of them. ${ }^{47}$ The opposite thesis defended by Michael of Cesena's group recalled the Quo elongati of Gregory IX (†1241) of 28 September 1230, which first theorized the idea of a papal ownership on the material goods used by the friars. In Quid ponat ius vel dominium, albeit only in this work, Olivi also looked at the question in specifically legal terms. ${ }^{48}$ Nicholas III himself adopted the basics of Quo elongati in his Exiit qui seminat. In this latter, after laying down five possible legal relationships to material goods (proprietas, possessio, ususfructus, ius utendi, and simplex usus facti), he defined the Franciscans' relationship to any goods in terms of simplex usus facti. Indeed, as Nicholas explained, if someone 'can give up all other modes concerning temporal goods', none can renounce the simplex usus facti since 'simple use is necessary for sustenance. ${ }^{49}$ Simplex usus facti roughly corresponds to the same meaning of usus or ius utendi as a lack of any kind of ownership pointed out by the dissenting friars in their references to Bonaventure's opinion. However, with respect to this source, it is worth noting that Nicholas slightly 'changed [its] terms': 'while taking over the substance of Bonaventure's argument', Nicholas increased from four to five the possible relationships to material goods originally considered by Bonaventure, 'presumably to give [them] a greater precision'. ${ }^{50}$

\section{The Final Break: The Election of Gerard of Odo to the Office of Min- ister General of the Franciscans}

John XXII called for a new General Chapter to elect another Minister General in 1328. Gathering in Paris on 11 June 1329 under the presidency of Cardinal Bertrand de la Tour $(\dagger 1342)$, the Franciscans chose Gerard of Odo ( $\dagger 1349)$, a much less principled and more politically minded friar than Michael of Cesena, to take over the vacant position of the leadership over the friars as a vicar-general. Shortly prior to this event, Michael of Cesena, despairing of ever influencing the course of decisions, had

${ }^{47}$ See Shogimen, Ockham and Political Discourse, 47-48. For Gerard of Abbeville's opinion, see his Contra adversarium perfectionis christianae, ed. Sophronius Clasen, Archivum franciscanum historicum 31 (1938): 276-329; 32 (1939): 89-200. See the same argument in Ad conditorem canonem, col. 1226 (Appendix, 11).

${ }^{48}$ In 'Question de J. Olivi, Quid ponat ius vel dominium ou encore De signis voluntariis', ed. Delorme.

${ }^{49}$ Mäkinen, Property Rights, 96.

${ }^{50}$ Lambert, Franciscan Poverty, 152. For the opinion of Bonaventure that Lambert considers here, see his Apologia pauperum, 312 (Appendix, 12). 
secretly departed from Avignon to join the party of the prevailing challenger to the imperial throne, Louis of Bavaria. He did this in the company of William of Ockham, Bonagratia of Bergamo, and a few confrères on the night of 25 May 1328. The Bavarian's long-standing attempt to bring central and northern Italy under his control was finally defeated in February 1330, at which time Louis was forced to retreat to Munich. The Franciscan exiles joined his train to the north. William of Ockham's defence of the empire and his critique of the papacy were written in $\mathrm{Mu}$ nich. For modern historians, the works written in the local Franciscan convent from the spring of 1331 onwards represent a sort of running chronicle of the conflict. The doctrine of the self-grounded legitimacy of the empire, as embodied in Louis the Bavarian and defended by the Franciscan exiles, in particular Ockham, in the midst of the fourteenth century, was the climax of the antipapalist campaign in its entirety. The challenge to the papacy, lasting almost two decades, was powerful and threatening. Ockham spent his time in exile in Munich busily proving that the emperor's legitimacy did not depend on papal approval, as it was part of his rightful status as successor and heir to the Roman Empire. The legitimate possession of the title of Roman Emperor, according to Ockham, had been transferred to the Germans via the 'Greeks' (the Byzantine emperors): no break had occurred in the passage of powers from one emperor to another, so that the rulership linking the Bavarian Emperor to his Greek predecessors (thus, more importantly, also to his Roman forebears) was intact. ${ }^{51}$ A closer analytical examination of the question will enable us to compare these vicissitudes of imperial might with those of the papal power.

\section{Ockham's Usage of the Distinction potentia Dei absoluta/ordinata after Scotus, and that of John XXII}

Ockham rejected the view that it was the pope who provided the emperor and the other secular rulers with their temporal powers: 'neither the pope nor the Roman Church has by Christ's institution power regularly to entrust temporal jurisdictions to the emperor and other secular rulers; they can exercise them without his commission. ${ }^{2}{ }^{2}$ With closer attention

${ }^{51}$ Georges de Lagarde, La naissance de l'esprit lä̈que au déclin du moyen âge, IVGuillaume d'Ockham: Défense de l'Empire (Paris and Louvain: Nauwelaerts, 1962), 247.

${ }^{52}$ William of Ockham, Eight Questions on the Power of the Pope (Octo quaestiones de potestate papae), q. 3, ch. 2, in his A Letter to the Friars Minor and Other Writings, eds. Arthur Stephen McGrade and John Kilcullen, trans. by John Kilcullen (Cambridge: Cambridge University Press, 1995), 308. 
to papal claims of supremacy over the emperor, Ockham stressed that 'no one has power to entrust temporal jurisdiction to his lord. But the emperor is the lord of the highest pontiff, since the pope is the vassal of him'. ${ }^{53}$ Closer examination of the empire proved to Ockham that it 'preexisted the papacy; so in its origin it did not derive from the pope; and so it follows that it does not derive from the pope even after the institution of the papacy. ${ }^{54}$ Yet Ockham repudiated the notion that the papal unction and consecration of the emperor might be evidence of legitimacy and validity of power. He opined that the emperor's power required no external source of legitimacy and no approval by the pope in order to be legally exercised. ${ }^{55}$ These views illustrate what Lagarde had already maintained: that is, that the public institution in which Ockham was most directly interested was the empire. He discussed its definition and power, refusing any role as a guarantee for the pope. ${ }^{56}$

As we turn to consider the developments since that time, another, even more fascinating, point that arises is the issue of papal prerogatives. This relates not to the 'duellistic' aspects of the rift between emperor and pope, but to the pope's rights within the Church. On this point, Ockham, despite his personal issues with the pope resulting primarily from their theological exchanges on the question of poverty, refrains from any direct political attack on John XXII. For example, he does not take up the accusations of bribery and nepotism that abound in contemporaneous documents. He only deplores the fact that such acts reportedly happen and recommends investigating the nature of Peter's mandate more closely. Ockham instead focuses on the question of the extension of the pontiff's authority, asserting that it stood in need of analysis far more so than that of the emperor. Thus, as Lagarde put it, 'there is no better introduction to Ockham's thought than the study of the critique he made

${ }^{53}$ Ibid.

${ }^{54}$ William of Ockham, On the Power of Emperors and Popes (De imperatorum et pontificum potestate), ed. and trans. by Annabel S. Brett (Bristol: Thoemmes Press, 1998), ch. 19, 118. See the Latin text in Id., Opera politica, eds. Hilary S. Offler and others, 4 vols (I-III, Manchester: Manchester University Press, 1956-74; Iv, Oxford: Oxford University Press for the British Academy, 1997), IV, 312: '[Romanum imperium] fuit ante papatum; ergo in sui principio non fuit a papa; et per consequens nec post institutum papatum est a papa.' Offler's critical edition contains all Ockham's political writings, except the Dialogus de potestate papae et imperatoris, for the whole text of which we shall refer to William of Ockham, Dialogus de potestate papae et imperatoris; Compendium errorum Joannis XXII (Turin: Bottega d'Erasmo, 1966; facs. repr. of the ed. Frankfurt: Nicholas Hoffmann, 1614).

${ }^{55}$ Ockham's Octo quaestiones de potestate papae, q. 2, ch. 11, in Opera politica, III (1974), 91; see Appendix, 13.

${ }^{56}$ Lagarde, La naissance de l'esprit lä̈que, 247. 
of the pontiff's plenitudo potestatis. ${ }^{57}$ The question of papal power, or, in other words, of the concentration of the maximum temporal and spiritual powers in the person of the pope, is the subject of most of Ockham's political writings. ${ }^{58}$ Ockham's feeling of plenitudo potestatis and the distinction he makes between the pope's regular and occasional powers can be usefully understood in conjunction with the theological distinction between God's absolute and ordered power. ${ }^{59}$ Despite this, this proximity between regular and occasional power, on the one hand, and absolute and ordered power, on the other hand, is rarely mentioned in the relevant literature. Ockham draws on this issue from Scotus, to the extent that the 'markers' of Ockham's distinction of regular/ordered power $v$. occasional/ absolute power, reproduce at least in part Scotus's distinction between de iurelordered power and de facto/absolute power. A close-up of the most significant political events of the times, in particular the comparison between Ockham's positions and those defended on the same themes by John XXII in his sermon Deus autem, rex noster (I am thinking, of course, of the unequalled work of Eugenio Randi on the topic) seems to confirm this suggestion. ${ }^{60}$

It is indeed the case that John XXII himself had recourse to the concepts of plenitudo potestatis and potentia Dei absoluta. However, these notions were invoked by John to show the extent to which the whole effort of distinguishing was no more than an amusing-yet useless and, worse, misleading-argument. In John's view, we are confronted with the claim that God holds, first, an ordered power (the power through which he has ordered, through eternity, all that is to happen), and secondly an absolute power (the power by which he can change whatever has been established in the preceding way). There is, however, one point where John wholeheartedly endorses the distinction as effective and positive: that is,

57 'Il n'est pas de meilleure introduction à la pensée politique d'Ockham que l'étude de la critique qu'il a faite de la "plenitude de puissance" pontificale.' Ibid., 73.

${ }^{58}$ See in particular Ockham's Octo quaestiones de potestate papae, q. 2, ch. 3, in Opera politica, III, 20 (Appendix, 14).

${ }^{59}$ An opposite opinion is held in Arthur S. McGrade, The Political Thought of William of Ockham: Personal and Institutional Principles (Cambridge: Cambridge University Press, 2002), 199 n. 5: 'The absolute-ordinata distinction does not correspond at all well with Ockham's distinction between regular and casual power. To name but one important difference, Ockham denied that it was within the pope's own discretion whether to use his casual power'.

${ }^{60}$ Paris, Bibliothèque nationale de France, MS lat. 3290, fols $65^{\mathrm{ra}}-95^{\mathrm{vb}}$, in Eugenio Randi, "Il rasoio contro Ockham? Un sermone inedito di Giovanni XXII," Medioevo 9 (1983): 179-98 (partially ed. also by Eugenio Randi, "La vergine e il papa. Potentia Dei absoluta e plenitudo potestatis papale nel XIV secolo," History of Political Thought 5 (1984): 425-45 [434-35]). 
the movement through which the place of power moves away from God and towards mankind. John offers his own position as a paradigm of this movement: namely the attribution of the plenitude of power to the pope. According to this application of the distinction between potentia ordinata and absoluta, the papal prerogatives would include the authority to change or 'overrule' what has been ordered by others, in particular-if we refer this argument to John XXII's positions in the poverty debates-by another incumbent of that same office, that is, an earlier pope.

Others claim that by 'ordered power' we mean the power by which God has ordered from eternity that which is to happen, and by 'absolute power' the power by which he can suspend whatever has been ordered from eternity; the same is to be said of the pope, according to those who claim that he can change, by the fullness of his power, whatever has been ordered by others, especially if it does not concern faith. ${ }^{61}$

Interestingly, this does not satisfy John, who remains critical of the distinction even in this respect. He, John, successor of Peter to the Holy See, is in no way disposed to allow the drawing of such a conclusion. In his view, it would be illegitimate to invest the pope with such an absolute power. If the pope has to part ways with earlier papal choices (a possibility that John certainly does not rule out) if he can modify what has been ordered by others, then such an intervention is allowable only in view of the limited foresight - which a pope shares with every other human being —of what has yet to happen. Whenever events take a different turn then expected and when unpredicted necessities arise, the pope will hence legitimately be able to take another course than that his predecessors have established. But this does not evince a real analogy between God's and the pope's power:

Brother, I do not understand it in this way and I do not think it is the true way. Rather, if the pope can modify those things that have been ordered by others, he can do so owing only to the human inability to foresee everything. Therefore, whenever things take a different turn from what had been expected and when unpredicted necessities come up, we are required to order things

${ }^{61}$ 'Alii dicunt intelligimus ordinatam potentiam illam qua Deus ordinavit ab eterno fienda; absolutam vero illam que potest suspendere illa que ab eterno sint ordinata; sicut est de papa, ut dicunt qui de plenitudine potestatis potest immutare illa que ab aliis ordinata sint, maxime si non tangant fidem.' Ibid., $\$$ XII, in Randi, "Il rasoio contro Ockham?," 191. 
otherwise. All this happens, thus, clearly not because there is power, but much rather because there is a lack of power. Power is, on the contrary, in God, who foresees everything infallibly, to whom everything is present, who ordered everything from eternity. ${ }^{62}$

Such positions seem, in a certain way, to emerge also from John's decretal letters on the question of poverty, where (see his Quia nonnunquam) he assumed, at least as a matter of principle, the right to revoke a decision taken by an earlier pope.

Dealing with the legitimacy of papal interventions, Ockham, on his part, seems to share somewhat John's observations on the exceptional permissibility of a papal action in the ordinary course of events as it was established in the past. Yet the limits he imposes upon such legitimacy circumscribe its range so narrowly that it makes papal action nearly impossible. Ockham starts by observing that from Christ's words to Peter providing him with binding power one cannot infer that all mortals are to be subject to Peter's successors in everything and with no exception, at least not those who have in themselves a valid plenitude of power over all mankind, both in temporal and spiritual realms. Ockham reaches this result also by distinguishing between the canonistic concept of papal plenitudo potestatis and the theological concept of potentia Dei absolu$t a$. Despite the difficulty of understanding the relationship between the two concepts, Ockham denies the potentia absoluta as an attribute of the pope, at least as a matter of principle. ${ }^{63}$ 'In the case of Christ's commission of the Church to Peter, Ockham rationalized the divine will rather than absolutizing it. ${ }^{64}$ If it does not constitute a complete refutation, the

62 'Frater, nec istud intelligo, nec verum credo, unde quod papa possit immutare illa que $\mathrm{ab}$ aliis ordinata sunt hoc est propter defectum humane providentiae, que non potest omnia previdere; et ideo quando veniunt casus et necessitates improvise oportet quod aliter ordinetur in multis. Et ita patet quod illud non fit propter potentiam, sed magis propter defectum potentiae: sed in Deo est e contrario qui omnia previdet infallibiliter, ymo omnia sunt sibi presentia, et ita ordinavit ab eterno omnia fienda.' Ibid.

${ }^{63}$ That Ockham's position does not imply a complete refutation of the notion of absolute power when referred to the pope is proved, already before his dealing with the debates over poverty, by Quodlibet VI, q. 1, 492: 'And these things God is said to be able to do by his absolute power. In the same way, there are some things that the pope is unable to do in accordance with the laws established by him, and yet he is able to do those things absolutely.'

${ }^{64}$ McGrade, The Political Thought of William of Ockham, 199 and n. 5. See also Randi, Il sovrano e l'orologiaio, 89-90: 'Ogni volta che la teoria della potentia Dei absoluta non è terreno su cui avventurarsi per accusare il papa di eresia, Ockham brevemente sembra accennare ad una tesi che ponga in relazione potentia absoluta e plenitudo potestatis papale. Si noti che egli non sembra mai premunirsi di confutare un simile nesso, puntando piut- 
pope's ineligibility to hold absolute power on a regular basis still proves, in Ockham's view, that absolute power plays a rather limited role in the definition of papal power. ${ }^{65}$ The core concern here is the conviction that Peter himself did not receive from Christ a plenitude of power sufficient to enable the Roman pontiffs, vel pro Romanis pontificibus se gerentes ('or those passing themselves off as Roman pontiffs'), to do anything prohibited by divine or human law. ${ }^{66}$ Ockham argues that it is because this is constantly overlooked that Christianity is so frequently haunted by never-ending troubles. When making Peter the head and prince of the faithful, Christ did not endow Peter with a plenitude of power, temporal or spiritual, allowing him to act, as a matter of course, against or outside that which had been established by divine or natural law. Christ had, instead, circumscribed his own power with limits that ought not to be exceeded. ${ }^{67}$ Consequently, the pope could only do something contrary to what higher laws ordered secundum quid, since plenitudo potestatis did not normally allow anything against them except in limited cases, such as a dispensation from an oath or vow by which an individual has bound himself or herself to God. ${ }^{68}$ Ockham so strongly insists upon the exceptional character of such cases that it is easy to infer that under any normal circumstances the pope can act only by means of actions that do not contravene divine or natural law. An action transgressing these rules cannot occur either on a normal basis or because the pope himself wanted it to happen, since his plenitude of power-by Christ's own decree and thus by divine law-does not exceed a merely occasional, situation-bound rule. ${ }^{69}$ In a more general sense, the pope can only overstep limits imposed to his power secundum quid and pro bono communitatis. He would not draw from Christ a capacity to intervene on a regular basis in temporal events, this being a prerogative belonging to kings, princes, or people tosto sulla fallacia del concetto di plenitudo potestatis: sembra insomma che per Ockham la distinzione non possa trovare un ruolo nella definizione del potere del papa.'

${ }^{65}$ William of Ockham, Tractatus contra Benedictum, in Opera politica, III, 273, quoted in Randi, Il sovrano e l'orologiaio, 89; see Appendix, 15.

${ }^{66}$ The quotation is taken from William of Ockham, On the Power of Emperors and Popes, ch. 1, 74-75.

${ }^{67}$ Ibid.

${ }^{68}$ Ockham, Dialogus, III, I, 1, 4, 775; see Appendix, 16. See Pennington, The Prince and the Law, 109 (which also refers to this locus ibid., n. 124): "When Ockham discussed the authority of the pope or the prince, he normally used the term 'plenitudo potestatis'. Whether applied to the pope or the emperor, 'plenitudo potestatis' did not allow the prince to violate divine or natural law, although the pope could, with cause, dispense from higher laws."

${ }^{69}$ Ockham, Dialogus, III, 1, 1, 16, 784-85; see Appendix, 17. On this account, see Randi's Il sovrano e l'orologiaio and "La vergine e il papa," which also refers to this locus, respectively at $89-90 \mathrm{n} .11$, and 432 n. 19. 
from the laity. Exceptional cases would be, for example, when the temporal realm is ordered in a way that imperils the Christian faith or community, or when events take a turn in favour of the Devil and no layman appears willing and able to put a stop to it. In these circumstances, the pope has the capacity to act, by divine law, in temporal events by doing what proper reason dictates necessary to preserve the common good or defend the faith or, ultimately, to avoid other dangers of the same kind. ${ }^{70}$

In determining whether these arguments are Ockham's personal inventions or whether others used this distinction before him, I shall turn to evidence presented by Gregory of Rimini, who speaks about the question in terms of a usitata distinctio around $1344 .{ }^{71}$ Such a statement is simple and sufficiently linear to escape interpretative danger. Gregory of Rimini refers to the extensive debate that the question of God's power had already engendered in his time, allowing modern readers to appraise the impact the distinction would eventually have on the evolution of legal-political ideas. But when and how did such an impact occur? We cannot exclude the possibility that, to some extent, such considerations had already emerged in Peter Lombard. But it is only much later, presumably in the comments to the Sentences, that the distinction was used in fields beyond the limits of cosmology or theology, properly speaking. The change in usage seems to have begun somewhere around the second half of the thirteenth century. And yet, the gesture of suspending all substantial differences between God and his creatures with respect to the ultimate goals of both their actions and habits emerges repeatedly as a distinctive feature from the late twelfth century onwards.

The arguments that Ockham draws from the distinction between potentia absoluta and potentia ordinata are clearly based upon John Duns

${ }^{70}$ Ockham, Dialogus, III, 1, 1, 16, 786; see Appendix, 18.

${ }^{71}$ Gregory of Rimini, Lectura super primum et secundum sententiarum, I. 42.-44. 1. 2, (Respondeo), eds. Damasus Trapp and Venicio Marcolino, III (Berlin and New York: De Gruyter, 1984), 368; see Appendix, 19. The manuscript Gregory of Rimini, Super primo et secundo sententiarum [...] [Venice: Giunta, 1522; repr. 1955], fol. 162 ${ }^{\mathrm{vb}}$ refers to the terms "usitatam quaestionem" in place of "usitatam distinctionem". These two references of Gregory to the question of God's power, including the passage quoted in Appendix, 19, were already highlighted by Randi, Il sovrano e l'orologiaio, 17 and n. 11. On Gregory of Rimini's thought, see in particular: Paul Vignaux, Justification et prédestination au XIVe siècle: Duns Scot, Pierre d'Auriole, Guillaume d'Occam, Grégoire de Rimini (Paris: Leroux, 1934; repr. Paris: Vrin, 1981); Gordon Leff, Gregory of Rimini. Tradition and Innovation in Fourteenth Century Thought (Manchester: University of Manchester Press, 1961); Onorato Grassi, "La questione della teologia come scienza in Gregorio da Rimini," Rivista di filosofia neoscolastica 68 (1976): 610-44; Id., "Lagostinismo trecentesco," in Storia della teologia nel Medioevo, ed. Giulio d'Onofrio, III (Casale Monferrato: Piemme, 1996), 605-43. 
Scotus's theology. In Scotus, the division of power operates, as it would later for Ockham, so deeply that it can indeed be used as one of the basic structures of his system of thought. ${ }^{72}$ Scotus also had quite profound influence in relation to Ockham's metaphysics. Indeed, similar to Scotus, Ockham regarded God's act of creation first of all as the law of ordered nature in a sense that has to be understood as not necessary inasmuch as it responds to the divine will that is intimately free. Only secondary causes, once they have been established, can act in a necessary way, the only exception being mankind-for mankind, to the extent to which humans are endowed with will, can still operate in a contingent way. We will return to this point shortly with respect to Scotus's notion of free agents. For now, it is sufficient to note that the distinction in Ockham begins first in connection with his metaphysics and cosmology and only later switches to a legal-political significance as a consequence of the debates on poverty and the power of the pope. The issues at stake in Ockham's investigation of nature, and in Scotus as well, are not fundamentally different from those with which earlier generations of theologians had been concerned. Is it legitimate to consider God as being bound by the law of nature that he himself established at an earlier date? Is God, in other words, capable of acting differently today than he did at the moment of creation, or is such a prerogative to be excluded once his creation has taken place? And, finally, could this latter possibility be seriously entertained if we consider, according to tradition, that God's action is free and not necessary? Such questions had determined, long before Scotus's times, the twelfth-century debate between Abelard and Lombard. These same questions still played a decisive role when the late-sixteenth-century infinitist revolution undertaken by Giordano Bruno $(\dagger 1600)$, in the wake of the heliocentric theory offered by Copernicus $(\dagger 1543)$ in his De revolutionibus orbium coelestium, was in full force. Elements of the discussion and the doctrines at stake were the same in both cases, with the sole exception of Copernicus's theories. These gave rise to absurd theological constructions, such as - drawing on a famous passage of Plato's Timaeus in the Calcidian edition—the doctrine of God's envy. ${ }^{73}$ Admitting that

${ }^{72}$ For a different opinion with respect to Ockham, see McGrade, The Political Thought of William of Ockham, 198-99.

${ }^{73}$ Plato, Timaeus, 29e in Timaeus a Calcidio translatus commentarioque instructus, eds. Jan H. Waszink and Povl J. Jensen (London: The Warburg Institute; Leiden: Brill, 1962), 22, quoted in my Diritto e teologia alle soglie dell'età moderna, 65; see Appendix, 20. I discussed the role the notion of invidia Dei, starting from Plato's Timaeus, played in the mediaeval and early-modern investigation of God's almightiness and particularly in the distinction between God's absolute and ordered power, see ibid., 59-80 (ch. 4, entitled 'Potentia Dei (absoluta)' e onnipotenza divina: dottrina cristiana e origini della questione), and in my "L'infinito universo e la distinzione potentia absolutalpotentia ordinata in 
God, after having created the universe, can still exercise an entirely free power and create a different and better world than the one he created would unavoidably lead to admitting a God who, although infinitely good, is nonetheless envious, and thus not immune to the deficiencies typical of human beings.

But to John Duns Scotus, writing in the years straddling the end of the thirteenth and the beginning of the fourteenth century, and to Ockham, a generation later, Peter Lombard's view that God can act otherwise than he did was still unassailable. ${ }^{74}$ This is particularly obvious in Ockham's case. In his opinion, it was still in God's undiminished power to create, for example, a different human, one that loathes sin rather than being tempted by sin, or to create individuals out of a different natural species, or simply to create a different and better world. ${ }^{75}$ No less than for Lombard, for Ockham this is a matter of principle. God is not bound by a law of nature; he may have created and he still can create worlds different from the one he has effectively created. And yet there is no evidence that either Scotus or Ockham has affirmed or assumed that God, having established the order of nature, then transgresses it by means of an absolute power that is different and stronger than that through which he created the universe and ordered his creation. This depends on the particular quality of God's omnipotence. The prevailing theological account submitted divine almightiness only to the law of non-contradiction in order to avoid the illogical outcome of a God at once willing and not willing, existing and not existing. This being said, even such a merely 'factual' intervention as the one corresponding to God's 'absolute' power-which, for Ockham and almost all of his intellectual ancestors, played only the role of a rejected hypothesis—should not be interpreted as arbitrary. In fact, it seems safe to say that any correct understanding of the 'absolute' character at stake corresponded to the idea of God's equally

Giordano Bruno," Annali di Studi Religiosi 13 (2012): 159-79, and "La potentia non invidia l'essere. Cosmologia, teologia e diritto in Giordano Bruno" (forthcoming 2019). For an account of the relationship of the mediaeval context with ancient Greek scholarship, see Adriano Magnani, "Fthonos theou: rifunzionalizzazioni di un concetto dall'Antichità al Medioevo," in The Theology of potentia Dei and the History of European Normativity (= Divus Thomas, 115, no. 2), 402-17.

${ }^{74}$ See the explicit reference to Lombard in the inception of Duns Scotus's Ordinatio I, 44, in Id., Opera omnia, vi, 363-69 (363) (see Appendix, 21, also for nn. 76 and 78 below) and in Ockham's Quodlibet VI, q. 1, 492: 'For there are many things God is able to do that he does not will to do, according to the Master of the Sentences, book I, dist. 43, n. 9'.

75 William of Ockham, Scriptum in librum primum sententiarum, dist. 44, in Id., Opera philosophica et theologica, eds. Girard J. Etzkorn and Francis E. Kelley, IV (St Bonaventure, NY: Franciscan Institute Publications, 1979), 652-53; see Appendix, 22. 
absolute goodness that was implied in such an omnipotence. The identity of the absolute character attributed to both followed strictly from the notion that God must be understood as a reality that is both one and simple. Will and intellect (and reason, as well) are one and identical in God. Most importantly, the effect of God's action is not pre-ordered by any ratio aeterna whatever, which would allow created beings to claim the character of universal and essential things per se. They are, on the contrary, the product of a fundamental freedom by means of which God, among an infinite variety of possibilities, fulfils his own unfathomable will.

\section{Scotus: God and Man as 'Free Agents'}

All these assumptions-Ockham's above-mentioned distinction between exceptional/absolute and regular/ordered powers of the pope and Scotus's version between de facto/absolute and de iurelordered powers-involve an unmistakably legal implication. Ockham, however, although he clearly shows himself to be confident in Scotus's account of the distinction and with his notion of 'free agents' in particular, prefers to limit his own attention to the case of papal power. But what does Scotus's notion of free agents consist of? The answer will further highlight the extent to which Ockham's arguments depended on Scotus.

It is certainly helpful to our case to engage in closer inspection of some implications of the fundamental dist. 44 from Scotus's Ordinatio I. As Scotus phrases it, not just God but every free agent could be defined according to the two forms — or, as we may say, criteria—of absolute and ordered power that theologians use in reference to God. In every free agent whose action is moved by the two principles of intellect and will, and is at the same time in conformity with an upright and just law, but being so not because of necessity, it is possible to distinguish between an ordered and an absolute power. ${ }^{76}$ In a sense, in light of Scotus's statements, the age of the potentia Dei absoluta and ordinata could be seen as already behind him, as he enters a new age in which the two forms of power are the predicate of any actor, meaning by this term not just God

${ }^{76}$ Scotus, Ordinatio I, dist. 44 (n. 3), in Id. On the Will \& Morality, selected and trans. with intr. Allan B. Wolter, trans. ed. William A. Frank (Washington DC: The Catholic University of America Press, 1997), 191: 'In every free agent acting intelligently and voluntarily that can act in conformity with an upright or just law but does not have to do so of necessity, one can distinguish between its ordained power and its absolute power.', For further references on this point, see La puissance et son ombre, ed. Boulnois, 57, 279 ff.; Schütz, “A Quandary Concerning Immanence," 202. 
but all free beings, be they angels, lawgivers, or men in general. But not all categories of being can be understood as acting in the same way. It is only if and when the legal rule is dependent on the agent's will that they can go beyond or against it. Otherwise, when the legal rule is not submitted to the agent, but to someone else, 'of course he can overrule it, but he may not: it is a forbidden act, and he is trespassing the law-he acts in a disorderly manner, disobediently' and, in a sense, '[he] sins. ${ }^{77}$ In other words, according to Scotus, every free agent can act by ordered and absolute power: by the first when their action respects an established legal order; by the second when they go beyond or against a legal rule. In the case of lawgivers, such a legal rule is imposed by the actual ruler or promulgated by one of his predecessors.

And therefore it is not only in God, but in every free agent that can either act in accord with the dictates of a just law or go beyond or against that law, that one distinguishes between absolute and ordered power; therefore, the jurists say that someone can act de facto, that is, according to his absolute power, or de iure, that is, according to his ordered legal power. ${ }^{78}$

Scotus's assumptions on this point sound quite juristic: in every free agent-Scotus affirms - one may distinguish between an action de facto or de potentia absoluta and an action de iure or the potentia ordinata. By so doing, the Subtle Doctor seems to deliver the most perfect illustration of the usage that the distinction has come to acquire by his time in terms of law. What he says of God may be used, mutatis mutandis, in reference to any free agent by intellect or will. Nonetheless, when Scotus proceeds with his reasoning, further considerations arise, highlighting, among 'free agents' by intellect and will, the two peculiarities of the distinction when it is referred, on the one hand, to lawgivers and, on the other hand, to God only. Every free agent has the possibility of acting otherwise than what has been established at an earlier moment. Yet it is only where his action is immediately legislative that this will have consequences for the legal order. Otherwise, that is, where the violation is not itself invested with normative effects (because the free agent is not the actual and rightful ruler), such an act is regarded as disorderly, unjust, and- to the extent that the transgression counteracts the divine order-sinful. In other

77 Olivier Boulnois, "From Divine Omnipotence to Operative Power" (= Divus Thomas 115, no. 2), 83-97 (91). On this point, see also Marilyn McCord Adams, William Ockham, 2 vols (Notre Dame, IN: University of Notre Dame Press, 1987), II, 1190-98.

${ }^{78}$ Scotus, Ordinatio I, dist. 44 (n. 3), in Id., On the Will \& Morality, 191 (with my changes). 
words, it is only 'within the power of the lawgiver to act contrary to the established law without acting illegally'. ${ }^{79}$ Yet in even narrower terms, it is only in God's case that such acts become immediately right, simply because it is the divine will that has given rise to it, as God alone can be conceived as acting always in an orderly fashion. ${ }^{80}$ When God acts beyond or against a certain course of action that he has already established or ordained, such an action cannot be defined as illegal or as marked by an intention to counteract the order of things. Rather, it gives rise to a new and different order, a new régime that is ipso facto no less ordered than the preceding one. In this way, an order is always ordered per se and not by means of its conformity with that of any 'predecessor':

Therefore I say that [God] can do many other things in an orderly fashion; and that many other things can be done in an orderly fashion, by those [actors] who act in conformity with those laws. This does not involve a contradiction when the righteousness of such a law-according to which one says that someone acts in a just and orderly fashion-depends on the power of the agent himself. Hence, insofar as [he] can act otherwise, [he] can establish another upright law-which, when it is set up by God, is [immediately] right, because no law is right except insofar as the divine will accepts it as established. ${ }^{81}$

What becomes visible in all these assumptions is Scotus's feature characteristic of attributing value, with a hitherto unseen explicitness, to contingency. At every moment, the new order established by the free agent can be revoked and replaced by a different one, which itself can be overturned the following moment. A free agent's range of action always includes the possibility of making a different choice and revoking its own earlier choice. With Scotus, everything that derives from the will of a free agent is contingent and not necessary. This also includes the definition or redefinition of the legal horizon within which such a contingent nature is deployed. It means that the order established through law is based on precarious, perennially changeable foundations. Even the definition of sin that fits into such a conception of order is evidence of this fact. It depends on a free choice of God, who alone can decide whether an ac-

${ }^{79}$ McCord Adams, William Ockham, II, 1191.

${ }^{80}$ See Ockham, Quodlibet VI, 491: 'Nor should the distinction be understood to mean that God is able to do certain things ordinately and certain things absolutely and not ordinately. For God cannot do anything inordinately.'

${ }^{81}$ Scotus, Ordinatio I, dist. 44 (n. 8), in Id., On the Will \& Morality, 192 (with my changes). 
tion is good or bad, and who alone retains the possibility of legitimizing an action hitherto defined as disorderly and prohibited, such as theft or murder. Scotus's radical understanding of the notion of contingency, the fact that his thinking is both structured and guided by the distinction between ordered and absolute power, informs his thought as applied in all spheres: from the ambit of morals to that of law to the investigation into nature. Yet law occupies a special position in Scotus's conception of the potentia Dei. While the investigation into God's power and the distinction between absolute and ordered takes its origin from theology, the growing presence of law, lawyers, legal uses, and proceedings has by Scotus's time established new horizons of action and meaning.

\section{God as Unity and Simplicity: Eckhart and Ockham}

Turning back again to Ockham and looking now into his positions with respect to those of Eckhart, I may begin by repeating what I said in opening this paper: that is, that the very first feature that authorizes a comparison between them lies in the importance that God's unity and simplicity assumes for both writers. By focusing on Ockham's metaphysics, it is worth noting an important aspect of his notion of natural law. Natural law in the version of Paul to which Ockham refers is an inheritance from Scotus, or more specifically from the question of Revelation that came to Ockham through the Subtle Doctor. Indeed, Scotus had himself firmly defended the primacy of Revelation, of theological truth, over any necessarian or causal logic. Ockham would eventually do so, despite the specific importance of natural philosophy in his thought. Overall, both Scotus and Ockham (and Eckhart, as well) were indeed, and remained, theologians. Even Scotus's notion of contingency hints at his final identity as a theologian and, as such, at his convictions that natural contingent order is nothing more than an orderly course of divine action that God could always overturn. Thus, at the conclusion of some ironic and witty observations, Scotus has recourse to an Avicennian source and scoffs at his adversaries' positions by recommending that all those who deny contingency be tortured until they admit as equally possible that they could equally well not be tortured. ${ }^{82}$

${ }^{82}$ John Duns Scotus, Quaestiones in librum primum sententiarum, 39. 5, in Id., $O p$ era omnia, ed. Luke Wadding, v, 2 (London: Durand, 1639), 1299-1300; see Appendix, 23. The same point is investigated by Scotus in almost the same terms and language in his Ordinatio I, 39. 5, in Opera Omnia (Vatican edition), vI, 415, and in similar terms in Lectura I, 39. 5; but, in the first case, consider that distinction 39 is lacking in the original version of Ordinatio I and that the text reported therein is actually the outcome of a schol- 
Therefore, the horizon within which both Scotus and Ockham move is first and foremost theological. With respect to the most innovative consequences of their theories, which significantly contributed to hastening the crisis of scholasticism, they are sincerely willing to submit themselves to the authority of Scripture and, in this sense, to strive to maintain the status quo unchanged as regards the primacy of theology over natural philosophy. In this regard, the metaphysical framework of both their systems seems to be consistent with that of Eckhart, insofar as all three of them share an identical, conservative core message, based on a traditional metaphysics that hangs over all ethical content, no matter how much they disagree with each other in many other respects. Even more radical in this respect is Eckhart, in whose writings it is easy to find elements that are, relative to each other, heterogeneous, from Plotinus's Platonism to Islamic and Thomistic Aristotelianism. To the extent to which the founding principle of his preaching finally appears to be the One-Godhead and not the traditional God-Person of Christianity, Eckhart posits that man fulfils himself when he comes to partake of the nature of such a being one, which is the true summit of all creation understood as absolute. In comparison with this, being as multiple appears a pure nothing per se, on which is imposed de natura rerum the total and complete immersion into such a principle of undistinguished unity. The necessitarianism of Eckhart's theses and the terminology that these deploy are not alternative to those of Ockham. Where the very Ockhamian notion of ens contingens gave rise to an irreparable devaluation of this latter conception in favour of the one and simple God of Scripture, the Dominican master wholeheartedly preached that such a devaluation, which he identified with the being as nothing per se of the multiple, should lead man to finally become one with God. This happened by means of the enthusiastic tones through which he summoned the faithful to become nothing, leaving behind every materiality and worldly appetite, in order to be de gratia Dei what Jesus is by nature: the Son, that is, in the words of a paradox of great effect, he himself father of his Father.

arly reconstruction: see the introduction to John Duns Scotus, Contingency and Freedom: Lectura I 39 (that is, Scotus's Oxford lectures on Peter Lombard's Sentences, I. 39), intr., trans., and commentary by Antonie Vos Jaczn and others (Dordrecht: Kluwer, 1994), 1-41 (14). I am particularly indebted to Anton Schütz for his ironic and insightful comments on these passages during various discussions we had on Scotus during the series of colloquia we directed on the question of potentia Dei in 2011-13 and in the editing of the first volume of their transactions, wherein he also mentions Scotus's passage: see Anton Schütz, "Legal Modernity and Medieval Theology: The Case of Duns Scotus," Ordinatio I, D. 44," (= Divus Thomas 115, no. 2), 418-52 (442 and n. 28). 
Finally, once its veil of accidents is lifted, reality appeared to Eckhart as a principle of unity.

\section{Eckhart's Rejection of the Distinction potentia Dei absoluta/ordinata}

First and foremost, it is worth noting that Eckhart makes no explicit reference to the distinction between absolute and ordered power. ${ }^{83}$ On the other hand, it does not seem unreasonable to take Eckhart into account in this respect for different reasons. In Eckhart's time, the distinction was already part of the doctrinal debate, as proved by the above-mentioned phrase of Gregory of Rimini as well as by Albertus Magnus's and Thomas Aquinas's use of the distinction. The lack of direct references in Eckhart has to be understood in light of the goals of his writings. We have seen through Ockham how the distinction could be understood in a logical and not factual sense. This being so, one might easily appreciate how having recourse to the terminology of such a discussion was of no interest to an enemy of sententiarum subtilitas like Eckhart. Ultimately, Eckhart's Godhead was a God of paradox, one who can be distinguished simply because of his indistinction. Given this, it makes little sense to address the question, even if only to acknowledge it from a logical perspective. In his Expositio libri Sapientiae, Eckhart makes use of the opposition between the One and the Multiple in order to explain the ontological difference that separates God and his creation:

The One and the Multiple oppose each other. It should immediately be noted that nothing is more different from God than all those things that can be identified as from number, what is numbered or can be numbered, viz. from all things that are created.

${ }^{83}$ For an analysis of Eckhart's main issues in the context of the theology of God's power and in light of his German preaching, see Jean-François Malherbe, "Le dualisme inconfortable de Maitre Eckhart," in The Theology of potentia Dei and the History of European Normativity (= Divus Thomas, 115, no. 2), 288-307. In connection with the theology of God's power, Malherbe pays special attention to the notion of 'panentheism'-introduced in philosophy by Karl Ch. F. Krause $(\dagger 1832)$ —also with reference to a possible influence of Eckhart on Giordano Bruno's philosophy through Cusanus. Malherbe discusses these points also in the approach he proposes to Bruno and John of the Cross $(† 1591)$ in his "Hérésie et spiritualité: Jean de la Croix et Giordano Bruno," Les Cahiers Villard de Honnecourt 80 (2011): 91-101, and "Un approccio 'congetturale' al pensiero di Giordano Bruno," in Verità e dissimulazione. L'infinito di Giordano Bruno tra caccia filosofica e riforma religiosa, ed. Massimiliano Traversino (Naples: Edi, 2015), 209-22. 
Nevertheless, such a difference does not, according to Eckhart, indicate an absolute and overwhelming gap between God and human beings. At first glance, there seems to be no greater difference than that between God, defined as one and undistinguished, and his creation, identified as something numerical or numerable and distinct or distinguishable from something else:

Nothing is as indistinct as God. [...] The distinction between something that is indistinct and something that is distinct is greater than any two things are distinct from each other. [...] But indistinction [or: 'indistinguishability'] pertains to God, distinction [or: 'distinguishability'] pertains to the nature and essence of creation' ${ }^{84}$

In other words, God differs from his creation to the same extent that the multiplicity of the latter starkly opposes the absolute unity of the former. This is a largely recurring theme in Eckhart's writings, constituting an argument that will exert a great influence on Cusanus (†1464) one century later. See, for example, the metaphor of throwing the peas from the second book of the De ludo globi:

If a multitude of peas is thrown - with a single toss-onto a level floor, they arrange themselves in such a way that no pea is either moved or at rest equally as another and in such a way that each's $[s i c]$ place and movement is different. ${ }^{85}$

Here, multiplicity is exemplified by the movement of peas, which scatter to the ground at different instants and points, although they have all been thrown at one unique time.

Turning back to Eckhart, as several of his sermons testify, he seems to affirm that such a contrast has no foundation in the divine will: man is indeed given the chance to reach God and, by a state of grace, become

84 ' [...] unum et multa opponuntur. Iuxta notandum quod nichil tam distinctum a numero et numerato sive numerabili, creato scilicet, sicut deus, et nichil tam indistinctum. [...] Plus distinguitur indistinctum a distincto quam quelibet duo distincta ab invicem. [...] Sed de natura Dei est indistinctio; de natura et ratione creati distinction' (also for the preceding quotation). Meister Eckhart, Expositio libri Sapientiae, ch. 7, v. 27a (Et cum sit una, omnia potest), in Id., Die deutschen und lateinischen Werke, eds. Heribert Fischer, Joseph Koch, and Konrad Weiß, III (Stuttgart and Berlin: Kohlhammer, 1936), 481-94 (489).

${ }^{85}$ Nicolaus Cusanus, De ludo globi (The Bowling-Game), book II, n. 81, in Id., Metaphysical Speculations, II, ed. and trans. by Jasper Hopkins (Minneapolis, MN: Banning, 2000), 295. 
unified with him and hence share his condition of ens simplicissimum. This is possible only on the condition that man undertakes a path of internal purification, detaching himself from the materiality of being and from any ambition or temporal desire. Eckhart maintains, in particular, that there is in man a sign of God, which he defines as a spark of the soul, uncreated and uncreatable to the same extent to which God himself is uncreated and uncreatable, through which man, once having rekindled it through a divine 'kiss', comes to the summit of purification and is ready to place himself totally in God:

When the soul receives a kiss from the Godhead, then she stands in absolute perfection and bliss: then she is embraced by unity. In the first touch with which God touched the soul and continues to touch her as uncreated and uncreatable, there, through God's touch, the soul is as noble as God Himself is. ${ }^{86}$

It is precisely within such reasoning that the question of the two powers, even though Eckhart does not mention it at all, seems to play a role when Eckhart comes to the final paradigm of his German preaching: the birth of God in the man who has reached the state of maximum purification. With respect to this point, Eckhart uses a terminology that is typical of a heightened necessitarianism and defines God's donating himself to the pure man in terms of a duty he cannot neglect. God is destined to be born as the Son in the very depths of human soul at the time when the human soul is completely detached and uninterested in the world. Again, Eckhart defines such a relationship between God and man in terms of a rebirth of man to a new condition in which human nature is integrated into the divine nature, where this latter coincides more with what he calls the Godhead than with God properly speaking. Such Godhead is conceived as a 'simple ground' or 'silent desert that no distinction ever peeped, of Father, Son or Holy Spirit. ${ }^{87}$ In the new light of the birth of the Son in the depths of the soul, the latest teaching of Eckhart seems to consist in an absolute and complete rejection of potentia Dei ordinata and hence of the distinction.

${ }^{86}$ Sermon 68, in The Complete Mystical Works of Meister Eckhart, trans. and ed. Maurice O'Connell Walshe, rev. and foreword Bernard McGinn (New York: Crossroad, 2009), 334-40 (338). All the quotations from Eckhart's sermons will be from this edition.

${ }^{87}$ Sermon 66, 309-11 (311); see Appendix, 24, also for n. 88 below. 


\section{Eckhart's Necessitarianism and His Search for the Godhead}

Eckhart's rejection aims at man's being rejoined with and in God as the ultimate goal of creation, leaving no place for different and further endings. Of course, at the very same time that he makes himself a brave upholder of the reasons for such a rejoining, Eckhart is well aware that the path of perfection he requires from the faithful is strewn with difficulties that not all men are able to overcome. Materiality, vices, and worldly desires of all kinds come between man and God. Nonetheless, constituting the central concern of his arguments is the contrast between truth and appearance, unicity and multiplicity, inasmuch as he considered the final coincidence with man to correspond to God's will and hence to be the only way of human salvation. This is what Eckhart means when he insists that God has instilled, in creating man, the spark in the depths of his soul. Thus, man is called by God to his complete realization, and this is possible only at the end of the path of being purified of any form of worldly concupiscence. Only in this way can man fulfil God's will completely. It is also worth noting that Eckhart's necessitarianism on this point shows a sensitivity that seems to profit from the above-mentioned necessarian views of Abelard in the doctrinal debate in which his position conflicted with that of Lombard. This is another reason to distance Eckhart with respect to the ideas of his younger contemporary William of Ockham, or to those of his almost exact contemporary John Duns Scotus. Had not Abelard already believed that admitting the possibility of God having created (or creating) more or less than what he effectively created would lead to denying the infinite divine goodness asserted by Scripture? Abelard's necessitarianism leads Eckhart to acknowledge the ultimate aim of the true man who accomplishes his essence and brings himself ever closer to God until his divine spark is rekindled. This goal is to finally become one with the undistinguished Godhead. God has donated to each man a sign of him, the spark, uncreated and uncreatable light, as an act of infinite love towards creatures in order for them, whose destinies would otherwise be to remain within the imperfection of multiplicity, to return to him again. Such a spark of the soul is thus nothing else than the quality — or, even better, the power-by means of which man finally comes to discover God in the purest and truest way. Man discovers God in his proper nakedness. Eckhart warns us to be aware that such a spark is not nobler in the essence of our soul than the humblest or the greatest among our faculties, be they hearing or seeing or again any other power that is subject to hunger or thirst, to feeling cold or hot, and this happens because being is indivisible. Taken individually, 
all the qualities of the soul are more or less noble than each other, but not in their inner being, which is one and equally noble for all of them. And only after man has turned his back on all created beings, even renouncing himself, will he be able to accomplish the one holy being that is present, thanks to the spark, in his soul. Unencumbered by any imperfection that is determined by conditions of time and space, the spark is in opposition to all being-and hence to their multiplicity. It seeks nothing else but God, or God's naked essence, as the undistinguished Godhead, within which no distinction nor attribute of person was ever manifested.

\section{Pure Possibility and Potency in Eckhart}

To the extent to which the Godhead is a 'simple ground' and a 'silent desert into which no distinction ever peeped', it is the very pure possibility by means of which 'all things are moved, and all those receive life that live of themselves, being endowed with reason' ${ }^{88}$ Within the great variety of Eckhart's sources, I should like here to trace his reference back to Aristotle's notions of 'unmoved mover' and of 'potency'. The first, that of the unmoved mover, came to him through an important passage of Boethius $(† 524)$ on which he comments: 'God is an immovable good, remaining still in himself, unmoved and motionless, yet moving all things' ${ }^{89}$ The second, that of potency, is to be understood more in the sense of Aristotle's $\tau$ ò $\varepsilon v \delta \varepsilon \chi o ́ \mu \varepsilon v o v$, the pure 'can be' or 'might possibly be (and not be)', devoid of any predetermination both in a positive and a negative meaning, than in that of $\tau$ ò $\delta v v \alpha \tau o ́ v$, viz. the 'out-and-out power' or the 'being capable of something', which is always meant to give rise to a specific and concrete determination. In Aristotle's words, if, with respect to the first meaning of potency ( $\tau$ ò $\delta v v \alpha \tau o ́ v)$, 'what is possible is possible at some time and in some way', 'with respect to what might possibly be'- that is, with respect to the second meaning of potency ( $\tau$ ò $\dot{\varepsilon} v \delta \varepsilon \chi o ́ \mu \varepsilon v o v)$ - the same opinion and the same statement are true and false at the same time'. ${ }^{90}$ Clearly, it is more the first than the second of the two meanings of potency that is functional with regard to the idea of God's perfection. Such an idea of perfection is destined to be realized when potency has been accomplished and dissolved. In this way, the maximum perfection

${ }^{88}$ Sermon 66, 311.

${ }^{89}$ Sermon 51, 270-73 (272); cf. ibid., 274 n. 16, and Sermon 66, 311 and n. 10.

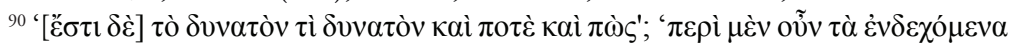

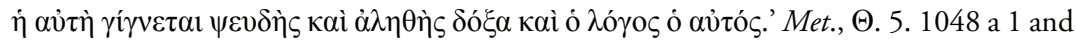
Met., $\Theta .10 .1051$ b 14-15, respectively. 
of God does not require potency, but takes the shape of a pure essence whose subsistence is not actually dependent on the attribute of 'can be'.

How do these arguments relate to Eckhart's notion of God, or, even better, that of 'pure possibility'? In light of the several German sermons that address the question, Eckhart's 'pure possibility' (grunt, in Eckhart's words) seems to highlight a strict familiarity with the notion of $\tau$ ò $\dot{\varepsilon} v \delta \varepsilon \chi 0$ $\mu \varepsilon v o v$, inasmuch as it too is revealed to be something that is behind and beyond, in Aristotle as well as in Eckhart, the same concept of potency. As a pure possibility, the Godhead does not finally consist in the second meaning of potentia or in the notion of the unmoved mover. Nor does it reside in the 'pure act' that, only a few years earlier, Eckhart's beloved Aquinas had analysed in such great detail. Precondition, hence, not annihilation. The silence to which Eckhart is referring when he comes to explain the concept of 'spark' benefits from the Aristotelian notion of potentia and thus becomes the cornerstone of Eckhart's ontology: the spark is the quality through which God provides his creation with both life and reason. Again, it is a real particle of himself that God, in his infinite love, instilled in mankind. Thanks to this spark, 'the soul becomes more one with God than the food with my body'. ${ }^{91}$ At stake here is a point that cannot be renounced by Eckhart. He investigates the question with all the creative capacity of his language in two similar sermons in which he comments on Luke 14.16-19.92 In this passage, the evangelist describes the great feast that a man, who represents none other than God, had organized and to which he had invited many people. In an important point of his explanation of the evangelical source, Eckhart gives us perhaps the most beautiful definition of his notion of spark. During the feast, the soul receives God in his entirety, and everything she wants is now available to her. All that God creates is subject to never-ending becoming, and yet in such a becoming the soul comes to discover, as it were reborn to a new life, a whole eternally present.

\section{Eckhart's Way to the Modern Era}

Eckhart's preaching of the One draws from a metaphysical-theological horizon that must not be disregarded in the building up of modern ideas. After all, scholarship has, with some important exceptions, mainly acknowledged the character of Eckhart's mysticism. The aim of this paper

${ }^{91}$ Sermon 32 (a), 191-95 (193).

${ }^{92}$ Along with the mentioned Sermon 32 (a), see Sermon 32 (b), 196-99. On the possibility that the two sermons are different versions of a same sermon, cf. Sermon 32 (a), 195 n. 1. 
is not to align itself with the many followers of that approach. Nor is it, on the other hand, to raise, as Kurt Flasch expresses it, 'objections [...] against the description of Eckhart as a "mystic" ${ }^{93}$ It is true that mysticism has represented and still currently represents, according to most scholars, the peculiar feature of Eckhart's preaching. But the question of what should (and should not) be defined as mystical is difficult to answer. One of several possible examples is Bonaventure's famous tripartition in his Itinerarium mentis in Deum. Bonaventure does not merely distinguish between different ways to attain knowledge of God, but shows three consecutive stages that man should traverse in his search for God. These stages represent three forms of theology: 'through symbolic theology we may rightly use sensible things, through proper theology, we may rightly use intelligible things, through mystical theology, we may be rapt to ecstatic transports..$^{94}$ Man gains a full comprehension of God only once he has arrived at the end of this journey (itinerarium): then his soul is 'rapt' to a level of knowledge that his senses and even his reason are unable to fully understand. In other words, according to Bonaventure, man can contemplate God only when he is free from sensory constraints and from his natural disposition to intellectual reflection. In a sense, religious experience is always also a mystical experience and approaching God inevitably consists in a path of 'detachment' from temporal things. Understood in this way, Eckhart's writings are doubtless mystical, given their goals.

Nevertheless, Eckhart's teaching continually has recourse to terms and concepts of scholasticism, and to Thomism in particular. This is evident not just in the Latin but also in the German writings of Eckhart, although Thomism may seem at first glance less suitable with respect to his German works, considering that these were directed to an audience not accustomed to scholastic discussions. Is this scholasticism consistent with Eckhart's mystical image? Or should we not consider Eckhart's writings, like those of other great masters of his time, as an attempt to investigate and rationalize the teachings of Christianity? Referring to Cusanus's writings, which contain much of Eckhart's metaphorical and paradoxical

${ }^{93}$ Kurt Flasch, Meister Eckhart: Philosopher of Christianity, trans. by Anne Schindel and Aaron Vanides (New Haven, CT: Yale University Press, 2015) Ebook; original German edition: Meister Eckhart: Philosoph des Christentums (Munich: Beck, 2010). For a further discussion on the opportunity of an inclusion of Eckhart within mysticism, with also references to Flasch and to the historiography that has been considering Eckhart from a mystical perspective since Romanticism or rejecting such an approach, see Karl Albert, "Epilogue: Meister Eckhart-Between Mysticism and Philosophy," in A Companion to Meister Eckhart, ed. Jeremiah M. Hackett (Leiden: Brill, 2012), 699-709.

${ }^{94}$ Bonaventure of Bagnoregio, The Journey of the Mind to God (Itinerarium mentis in Deum), trans. by Philotheus Boehner, ed., with intr. and notes, Stephen F. Brown (Indianapolis, IN: Hackett, 1993), 7 (ch. 1, \$7). 
language, is here extremely instructive and will help, if not to abandon the concept of mysticism in reference to Eckhart, at least to approach it in a more systematic way in light of his contribution to the subsequent history of ideas. ${ }^{95}$

Perhaps only Cusanus was really able to fully grasp the importance of Eckhart's writings for the new culture that became popular with humanism. Eckhart's notion of God caught in his nakedness is closely related to the hidden God of Cusanus, who deploys images and terminology that echo the Dominican master, for example such phrases as: 'in God all things are God, who is Absolute Necessity' ${ }^{96}$; '[God is] Form of forms and Truth of truths ${ }^{97}$ or 'Being of beings, and Essence (ratio) or Quiddity of things'. ${ }^{98}$ The One gives birth to the One only: this idea, coming from Avicenna, is the argument upon which both Eckhart and Cusanus built up their respective systems of thought. Moreover, the conviction that the truth to look for is One only and not multiple was common, an inspiration largely shared by any skilled theologian educated in scholasticism. The same Scotian-Ockhamian theology should be of help to these theologians, inasmuch as its major merit consisted in highlighting the inadequacy of every logic with respect to devising a theology based on a causal explanation of the order of natural things. Also Eckhartian in tone is the definition of God as the 'absolutely Maximum' (absolute maximum) that is 'negatively infinite' (negative infinitum), insofar as Cusanus, like Eckhart, meant by this expression the fallacy and inadequacy of any attempt to fully grasp nature by reasoning, but certainly not a value neg-

${ }^{95}$ Although it is not centred on the relationship between Eckhart and Cusanus, an insightful overview on Cusanus's speculation over the One, with a special focus on Scotus's influence on Cusanus and helpful reading in view of an investigation into Cusanus's knowledge of Eckhart's concerns, is provided by André de Muralt, Néoplatonisme et aristotelisme dans la métaphysique médiévale (Paris: Vrin, 2008), 77-99 (ch. 3, entitled La métaphysique cusaine de l'Un).

${ }^{96}$ Nicolaus Cusanus, De docta ignorantia, I. 22. 69, in Id., On Learned Ignorance: A Translation and an Appraisal of 'De docta ignorantia', ed. and trans. by Jasper Hopkins (Minneapolis, MN: Banning, 1985), 78. See the original Latin in the Latin-German critical edition of Cusanus's Philosophisch-theologische Werke, ed. and intr. Karl Bormann, I (Hamburg: Meiner, 2002), 88-92 (90): 'omnia in Deo sunt Deus, qui est necessitas absoluta' (see also Appendix, 25).

${ }^{97}$ Id., On Learned Ignorance, 110 (II. 9. 148). The whole sentence reads: 'absolute possibility [original Latin: absoluta potentia] or absolute form (i.e., [absolute] actuality) which is not God cannot exist. [...] there is only one Form of forms and Truth of truths and $[\ldots]$ the maximum truth of the circle is not other than that of the quadrangle.' Cf. Thomas Aquinas, Summa contra gentiles, I. 62 (Quod divina veritas est prima et summa veritas): 'Divina veritas est mensura omnis veritatis'.

${ }^{98}$ Cusanus, On Learned Ignorance, 104 (II. 7. 130). 
ative per se as an attribute of God. ${ }^{99}$ In Cusanus, all elements that should contribute to the rejection of the modus procedendi typical of scholastic Aristotelianism, inasmuch as it sought to explain being without knowing its foundation, relate to the ambit of faith. It is indeed Cusanus who first answered what is perhaps the major question posed by Eckhart: the relationship between God and man. Where, in an important passage that would be included within Eckhart's sentences condemned by John XXII, the Dominican sorted out the problem by warning that creatures are nothing in themselves and all in $G o d,{ }^{100}$ his pupil Cusanus specified his personal solution to a Christ regarded as immanent within nature, according to the famous dialectics of complicatio and explicatio. ${ }^{101}$ Creatures have been living and eternally live within the Verbum, that is, in God, although they do not identify with him if individually taken, but only when they are all in God, who, on his part, is in all of them. Creatures are 'complicated' (enfolded) in God and 'explicated' (unfolded) in the world. Cusanus's response is one that tries to preserve the relationship between God and his finite creation, which is finally made possible by Christ's mediation thanks to his twofold nature, human and divine at the same time. (The terms of the question would be used in a quite

${ }^{99}$ For the phrase 'negatively infinite' (negative infinitum), see ibid., 90 (II. 1. 97). The whole sentence reads: '[...] only the absolutely Maximum is negatively infinite.' Hence, it alone is whatever there can at all possibly be. For the original Latin, see Id., Philosophisch-theologische Werke, I, 12 (Appendix, 26). Cusanus further concentrates on God as infinitas negativa in his treatment of theologia negativa in On Learned Ignorance, 86 ff. (I. 26).

100 Sermon 40, 224-28 (226): 'All creatures are pure nothing. I do not say they are a trifle or they are anything: they are pure nothing. What has no being is not. All creatures have no being, for their being consists in the presence of God.' See the Latin version of the passage at art. 26 of the 1329 bull In agro dominico: 'Omnes creature sunt unum purum nichil: non dico quod sint modicum vel aliquid, sed quod sint unum purum nichil'; cf. note 1, 228, to the sermon. Among the different passages proving how central the point was to Eckhart's concern, see Sermon 94, 455-57 (456): 'Creatures are one in the one, and are God in God: in themselves they are nothing.' See Cusanus, On Learned Ignorance, 124 (II. 13. 179), where Cusanus has seeming recourse to Eckhart and says: 'all things are in Him and nothing is outside Him. He is the Beginning, the Middle, and the End of all things, the Center and the Circumference of all things [...] without Him all things are nothing'; 'in ipso sint omnia et extra ipsum nihil; qui est principium, medium et finis omnium, centrum et circumferentia universorum, $[\ldots]$ sine eo omnia nihil sunt.'

101 The dialectics of complicatiolexplicatio is the main subject of On Learned Ignorance book II; see, for example, the explanation of the relationship between God and creation ibid., 95 (II. 3. 111): '[...] God is the enfolding [complicatio] and the unfolding [explicatio] of all things, that insofar as $\mathrm{He}$ is the enfolding, in Him all things are Himself, and that insofar as $\mathrm{He}$ is the unfolding, in all things $\mathrm{He}$ is that which they are, just as in an image the reality itself (veritas) is present.' 
opposite direction in Giordano Bruno's theory of infinite worlds. ${ }^{102} \mathrm{We}$ have also seen above the question of possibility in relation to Eckhart's doctrines. And yet Eckhart's metaphysics of the One, at the very moment he affirmed the notion of pure possibility (grunt), appeared problematic with respect to the notion of potentia and intentionally avoided considering the notion of act. In this way, it was finally revealed to be beyond the same concept of potency, which had nonetheless arisen, in scholasticism, as the maximum attribute of God. In short, these views of Eckhart constituted a heterodoxy with regard to a Christian thinking that was then nearly unanimous in using the dialectics of act and potency to demonstrate God's existence as the almighty God of Scripture and that in the divine action acknowledged, by means of the attribute of potency, a clearly voluntaristic mark. What is the relationship between this heterodoxy and Cusanus's conviction that creatures have been living and shall eternally live within the Verbum in a complicated way? The consequences of such an assumption show a necessary character, which further underlines Cusanus's role, through this necessitarianism, as a bridge between two traditions of thought, the first that is turned back to the past and the second that extends to the Spinozan and Leibnizian 1600s. Everything is in God, God is in everything. From this it follows that God is all that he can be, esse and posse at the same time, or, through a Latin neologism created by Cusanus, possest (which means 'can be' or, better, 'can-is' as the verb 'to be' is declined in the third singular person). The posse is solved in the esse of God. Cusanus seems to be closer to Aquinas than to Eckhart in this notion of possest, in the extent to which it takes back, even while markedly changing it, the investigation started by scholasticism and also safeguards the idea of a finite creation. Actually, extending far beyond Eckhart's notion of pure possibility, Cusanus maintains that God is absolute potency and act at the same time, and that in God all that is potentially capable of existing de facto exists. Nevertheless, if this is really a matter of necessitarianism, Cusanus seems not to be fully conscious of its future consequences, and Cusanus's necessitarianism does not provide any concrete assertion that might explain such a necessity on the level of nature, as it will be with Giordano Bruno and later with Baruch Spinoza $(\dagger 1677)$. As to Cusanus, necessitarianism acts in the ambit of faith, not in that of reason. The foundation of nature remains explicable only in

${ }^{102}$ Christ's mediation in light of his twofold nature, human and divine at the same time, is the subject of De docta ignorantia III. For Bruno's usage, see Massimiliano Traversino, "Dogma trinitario e infinito universo in Giordano Bruno: spunti dal 'De docta ignorantia' di Cusano," in Verità e dissimulazione, 155-69, and Id., Diritto e teologia alle soglie dell'età moderna, 43-58. 
the limited field of faith, including any being whatever, either possible or actual, among God's creative possibilities.

\section{Conclusion: God's Powers, a True or an Alleged Distinction?}

Eckhart and Ockham seem the champions of two theses that are not counter-opposed, but are nonetheless distant from each other. Beyond the common elements we have seen, the distance that separates them is in a sense 'informed' by their different views on the question of God's power. The final absorption, in Eckhart, of man into the Godhead cut the distinction at its root, by eliminating the potentia ordinata. Logical or factual as it may be, the adoption of the distinction in Ockham showed, on the contrary, a certain diffidence with respect to the other of the two terms of the question, the potentia Dei absoluta. As said, he believed that God, after creation, did not transgress the order of nature he established by means of his absolute power (but he could, if he so wished) and then operated only ordinate. After all, the law of nature is characterized by an original vice: it is valid as long as God's potentia ordinata consents to it and can be overstepped at any moment by an act of divine disposition that is eternally unrestricted by what the order of nature would impose. The same knowledge of the world that man experiences is possible only by means of accidental beings, inasmuch as in nature no universal being is admitted. From this, it is therefore easy to derive the impossibility of an exact knowledge of the relationship between cause and effect, because natural causality is strictly dependent on the order God wanted de potentia ordinata and it inevitably follows the destiny of uncertainty of such a relationship. The relationship between cause and effect is hence determined as a mere explanation of a consequential relationship that is accidental and lacking the necessary character that is typical of eternal reason only. Causality of the second causes found in nature is revealed to be a determination of the first cause or divine principle, and man's ability to comprehend the relationship that binds the first and the second cause to each other is destined to be lost in accidental (natural) datum. Man is in fact not permitted to return to the knowledge of being as such. He cannot go beyond the acknowledgement that there is a nexus of the cause-effect kind that remains to him unknowable in itself. Anything apart from unfolded creation will then seem to lead to a criticism in which Kant's criticism itself has its origin, insofar as one admits that the 
thing per se shows the mark of a late Ockhamism. ${ }^{103}$ Man's capacities of judgement get barely a glimpse of what is hidden behind the chain of being, leaving man limited to perceiving the regularity of chronological succession of cause and effect, that is, reading the events by placing them in a consequential order when conditions that have given rise to them appear equal with respect to past events. In other words, if, on the one hand, natural causality, which stands de potentia ordinata, cannot be denied, on the other hand, we cannot attribute any necessary character to it. There is here no space for any form whatsoever of necessitarianism.

Courageously, Abelard in the 1120s, with his Sic et non, listed a series of assertions that contradict each other drawn from the Scripturesand the Fathers of the Church and to which he intentionally supplied no solution. ${ }^{104}$ Abelard was encouraging his audience to go beyond the easy dogmatism of a merely literal acceptance of religious texts. Ockham made use of this example to a different purpose: that of highlighting the limits of reason by juxtapositioning its rigidity (produced by its method of proceeding on the basis of the principles of causality and finalistic explanation of events) with divine freedom: God commits sin but does not sin; Christ's head is the foot of Christ; God can take the form of a donkey as well as that of a stone or wood; in transubstantiation, which lacks biblical foundation, two substances are equally present at one and the same time and in the same space; in the Trinity, God is one in three; etc. The separation that is here taking place between logic and theology, from which the negation of any possible rational theology derives, takes on a rather different significance later in the course of the history of ideas. However, the true goal of Ockham is quite separate. Like Scotus_-and perhaps more so-Ockham experiences the crisis of scholasticism in person. Once he has realized the fallaciousness of reason in matters of faith, as a man of his time, he throws himself in defence of the second and underlines its autonomy from logic (and vice versa). And it is indeed because of distrust in reason that Ockham relies completely on faith, believing that the only

${ }^{103}$ I have here in mind André de Muralt's definition of Kant as the 'last Ockhamian' in his "Kant, le dernier occamien. Une nouvelle définition de la philosophie modern," Revue de Métaphysique et de Morale 4 (1977): 32-53, repr. in his La métaphysique du phénomène. Les origines médiévales et l'élaboration de la pensée phénomenologique (Paris: Vrin, 1985), 138-59, and Muralt's remark around the continuation of the Ockhamian-modern theory of will and its liberal concept of freedom. On this second point, see André de Muralt, "La doctrine médiévale des distinctions," in Id., L'enjeu de la philosophie médiévale. Études thomistes, scotistes, occamiennes et grégoriennes (Leiden: Brill, 1991), 4789 (esp. 75-81).

${ }^{104}$ For the English critical edition of the book, see Peter Abelard, Sic et non: A Critical Edition, eds. Blanche B. Boyer and Richard McKeon (Chicago, IL: University of Chicago Press, 1976). 
absolute truth rests on it. Truth cannot be understood in a natural way, being rather the object of Revelation. Ockham does not justify miracles de potentia absoluta, referring them on the contrary to the order of nature created by God.

However, his theses are still founded on an explanation of a supernatural character. Irrationality can only be explained through the believer's acceptance of the content of faith, to which Ockham is inclined to attribute full normative character. In this way, he acknowledges whatever Scripture has said or whatever has been drawn from it, and resolves by faith every contrast between the latter and human reason. Ockham did this in the conviction not only that the only way to understand the content of Revelation was through conscience, but also that the cognitive path of such a comprehension is rooted in the-evangelical and Pauline-law of nature that man possesses owing to his nature as a moral being. Nonetheless, not even man has the character of universal being. The only ethical rule that is given to him has to be picked out, in a truly positivistic way, in God's will— to the extent that the just will coincides with what God has decided to be such among the infinite possibilities offered to him at the act of creation. The consequence is that for man, evil has to be defined as that something of which one is obliged to do the contrary, as good actions and bad actions differ only because the first correspond to the order accomplished by God and, if God so wanted, even murder and hate against him would cease to be bad. On closer inspection, such arguments do not exclude the freedom to choose otherwise, and man is always given the opportunity to do otherwise than has been established by divine decree. It is God, by contrast, as Scotus had said, who cannot will something that is not just, since God's will is the first rule, and when he decides to modify something, that something becomes ipso facto just. Such an argument is strictly connected to what we have seen above with respect to the possibility of disorderly conduct. It is no exaggeration to say, through recourse to Scotus's notion of the free agent, that human will is so free that man is always given the chance of voluntarily transgressing the divine order. Man, in other words, would understand by means of his intellect what God commands him, but would nonetheless be free to comply with it or not, and would be aware of committing evil should he disobey the divine commandment. Sin is, in this way, the decision consciously undertaken to disobey God. Will, which the intellect has made capable of understanding the divine prescription, acts for good or for evil. 


\section{John XXII's Pontificate and the Cases of Eckhart and Ockham: Con- servative and Innovative Tendencies}

The years of John XXII's pontificate appear decisive in several respects. The papacy underwent a twofold and testing conflict, on the one hand with the empire and on the other hand with the dissenting Franciscans and the unofficial orders. With regard to the first point, the pope reaffirmed once again his own authority in the temporal realm, an authority that in those years also came to be strengthened owing to the pope's residing in Avignon and the connected stabilization of the papacy as a financial and administrative system. Of course, one consequence of this was also the pope's subjection to the control of the French monarchy, the thorny neighbour of the papacy in its territorial location at the time. Avignon was indeed not subordinate to the King of France, but French influence was evident in the provenance of Avignonese popes and the consistent faction of prelates they appointed to roles of relevance in the administration of ecclesiastical offices. This influence illustrates the rising importance of territorial monarchies in the fourteenth century, which diminished the impact of the rivalry between the two universal powers of the time, papacy and empire. These were no longer the main protagonists in the political scene on the continent. This historical point, however, falls outside the goals of this paper. With respect to the second point of conflict, concerning the spiritual role of the papacy concerning contemporary religious orders, John XXII's reaffirmation of the pope's authority made extensive use of juridical notions. In the dispute over evangelical poverty, it is curious to note that it was the dissenting Franciscans and not the pope who maintained the principle of infallibility of papal acts. The distinction between the two above questions, the first relating to the struggle with the empire and the second relating to the control of the organization of the religious orders, was nonetheless not taken to extremes. These questions actually merged and operated in reciprocal interplay: in the case of the dissenting Franciscans, who, having fled from Avignon, took shelter at the court of the Bavarian; and in the case of Eckhart, who found himself entangled in heresy because of his activity as a preacher in lands where the papacy was persecuting autonomous religious communities. Both Eckhart and Ockham, despite their conservative positions on the role of faith and religion in the society of their times, made themselves unconscious and almost unwilling spokesmen of renovation. Eckhart did this by means of a metaphysics of the One representing an out-and-out revolution. He affirmed a dignity for man so great that man, once purified through faith by freeing himself from the multiplicity of 
being, becomes the peer of God, and both of them regenerate by melting into the undistinguished Godhead. We see something similar, even if only limited to the confrontation between human and divine normative acts, in Scotus, although he did not go so far as to assert a complete equality. The newness of the Scotian lesson on God's power would be reproduced, some decades later, in Ockham, who deployed it during the dramatic 1320-30s in his own contribution to the problems of religious faith and defence of the empire. The innovative character of Scotus's contribution, which is of specific interest to this paper, played out in the field of law and normativity. It seems clear, then, that the successful modern distinction between royal and popular sovereignty was drawn from such a theology of the two powers of God (first in Scotus's and later in Ockham's version). ${ }^{105}$ Furthermore, the modern era also clearly drew from this theology with regard to the 'paradoxical relationship' of today's constitutionalism, in which the two powers take on the roles of constitutive legislative power and constituted legislative power. ${ }^{106}$ Fourteenth-century man could not be aware of such later outcomes, of course. Others would take advantage of the innovative arguments he put into play in his conservative attempt to defend a society, his own, that was inexorably fading away.

\section{Massimiliano Traversino Di Cristo Centre d'Études Supérieures de la Renaissance Université de Tours}

The present text is a revised version of Chapter 3 of my Against the Backdrop of Sovereignty and Absolutism: The Theology of God's Power and Its Bearing on the Western Legal Tradition, 1100-1600 (Ph.D. thesis in tripartite cotutelle, Birkbeck College/University of London, University of Geneva, and University of Trento,2017) and collects part of the output of periods of research I did in Avignon. I gratefully acknowledge Julie Monnet, Isabelle Duval, Francine Mourier, and Laurent Vallière for their hospitality and the assistance they gave me during my stay in Avignon. On the same subject of this paper, see also my "The Western Church under Pope John XXII. Political and Theological Stakes in the Trials of Meister Eckhart and William of Ockham," Divus Thomas, 115, no. 1 (Jan./Apr. 2012), 368-89, and "Il processo di Maestro Eckhart, sintesi coerente del suo pensiero", presentation of Jean-François Malherbe ( $†$ Dec. 2015), 'Soffrire Dio'. La predicazione tedesca di Maestro Eckhart, ed. and trans. Massimiliano Traversino (Naples: Edi, 2013).

105 On this point, see Alois Dempf, Sacrum imperium: Geschichts- und Staatsphilosophie des Mittelalters und der politischen Renaissance (Munich: Oldenbourg, 1929), 505 ff., and André de Muralt, L'unité de la philosophie politique: de Scot, Occam et Suarez au libéralisme contemporain (Paris: Vrin, 2002), 115-56.

${ }^{106}$ Marinos Diamantides, "God's Political Power in Western and Eastern Christianity in Comparative Perspectives," in The Theology of potentia Dei and the History of European Normativity (= Divus Thomas, 115, no. 2), 333-81 (366). 
For my personal account of Eckhart's contribution to mediaeval and modern ideas, I am particularly indebted to Prof. Malherbe for the ironic, challenging, and inspirational comments he provided me while I was writing this paper and the above texts, and during the discussions we had in classes in Moral Philosophy we delivered to Ph.D. students of the University of Trento in 2011-12, and in various later occasions. That said, this and the abovementioned papers are my own.

\section{APPENDIX}

\section{1. (note 7)}

Nonnulli tamen profanae multitudinis viri, qui vulgariter Fratricelli [sic], seu fratres de paupere vita, Bizochi sive Beguini vel aliis nominibus nuncupantur in partibus Italiae, nec non in insula Siciliensis, comitatu Provinciae, Narbonensi et Tholosanensi civitatibus et dioecesibus et provinciis, aliisque diversis cismarinis et ultramarinis partibus, contra dictos canones habitum novae religionis assumere, congregationes et conventiculas facere, et superiores sibi ipse eligere, quos ministros, seu custodes vel gardianos, aut nominibus aliis appellant, plurimos ad eorum sectam recipere, et loca de novo construere, seu constructa recipere, in quibus habitant in communi, publice mendicare (quasi eorum secta foret una de religionibus, per sedem apostolicam approbatis) temeritate damnabili praesumpserunt, et praesumunt etiam incessanter. [...] Et quia in errorum barathrum faciliter ruunt, qui conceptus proprios patrum definitionibus anteponunt: ipsorum quamplurimi (sicut fide digna relatione percepimus) a veritate catholica fidei deviantes ecclesiastica sacramenta despiciunt, ac errores alios student multipliciter seminare. Cum itaque talium damnanda temeritas in eiusdem fidei detrimentum [...] $\&$ etiam suarum $\&$ aliarum animarum perniciem redundare noscatur, [...] de fratrum ipsorum consilio auctoritate Apostolica nullius fuisse $\&$ esse decernimus firmitatis: \& quatenus de facto processerunt de consilio $\&$ auctoritate praemissis, revocamus omnino, ac perpetuae prohibitioni subiicimus, \& ab ecclesia Dei poenitus abolemus. Eisdem personis \& aliis quibuscunque sub poena excommunicationis, quam eas (si secus fecerint) incurrere volumus ipso facto, iniungentes expresse, ne status sive sectam \& ritum huiusmodi ab ipsis assumptum sectentur ulterius, vel ipsum de novo assumere quoquo modo praesumant.

\section{2. (note 14)}

Ma tu che sol per cancellare scrivi, pensa che Pietro e Paulo, che moriro per la vigna che guasti, ancor son vivi. 
Ben puoi tu dire: 'I' ho fermo 'l disiro

sì a colui che volle viver solo

e che per salti fu tratto al martiro,

ch'io non conosco il pescator né Polo.'

\section{3. (note 15)}

Homo perstudiosus et vehementioris animi, hinc lectioni librorum inhiabat, illinc simultates acerbas et inextricabiles agens cum imperio romano alteram vite partem huic studio devoverat. Ceterum cum a legendo eum et senium et curarum varietas retardaret, gratissimus erat illi quisquis defloratos, ut proprie dicam, libros sub breviloquio perstringeret redigeretque in eas quas 'tabulas' vocant, in quibus omne quod ex libris quereretur facillimum esset inventu.

\section{4. (note 31)}

Per suspensionem autem huiusmodi nequaquam licentiam cuiquam intendimus impertiri, quod contra fratrum regulam praedictorum dogmatizare, scribere seu determinare, praedicare seu prave loqui liceat publice vel occulte; quin immo haec omnibus et singulis auctoritate praedicta districtius inhibemus.

\section{5. (note 33)}

Visis et examinatis dicta quaestione cum allegationibus, quae pro et contra fiunt, diligentique et matura deliberatione digestis, determinationi sanctae Romanae Ecclesiae firmiter et totaliter inhaerentes, concorditer et unanimiter dicimus et fatemur, quod dicere et asserere quod Christus, viam perfectionis ostendens, et apostoli eiusdem perfectionis viam sequentes atque per exemplum in alios, volentes perfecte vivere, derivantes, nihil iure proprietatis, domini seu iuris proprii, in speciali vel in communi habuerint, non est haereticum; sed sanum, catholicum et fidele, maxime cum sancta Romana Ecclesia catholica, quae e tramite apostolicae traditionis numquam deviasse aut errasse probatur.

\section{6. (note 37)}

Sequeretur etiam ex hoc quod ex quo dominus Nicolaus III fecit dictam declarationem, fuisset haereticus manifestus, et quod gesta per eum fuissent nulla et nullius valoris et momenti, et quod dominus Bonifacius VIII et Clemens V, ex quo talem determinationem approbaverunt, fuissent haeretici, et quod gesta per eos non tenuissent, et quod cardinales facti per ipsos summos pontifices, et qui consenserunt in ipsa determina- 
tionem, non fuissent veri nec legitimi cardinales, et quod ipse dominus Ioannes, electus ab ipsis, numquam fuisset verus papa.

\section{7. (note 39)}

Sed hoc Romanus Pontifex praedecessor noster, Nicolaus, quoad principalia tria vota, scilicet in obedientia vivere, et sine proprio, et in castitate, ac alia, si qua evangelio reperiantur expressa, in dicta regula videtur intellexisse dicere in declaratione praedicta, quod utique declarationibus nostris in nullo obviat supra dictis. Adhuc non apparet, ipsum dixisse, sustentationem Christi et Apostolorum eius in solo et nudo simplici consistere usu facti, quum quoad Christum et Apostolos nullam praefatus praedecessor noster Nicolaus in sua declaratione facerit mentionem. Immo sensisse satis videtur expresse, quod ius aliud a proprietate habuisse potuerunt, quum de sola abdicatione proprietatis, non juris alterius, in praefata declaratione, quantum ad ipsos attinet, mentio habetur.

\section{8. (note 41)}

Honorius quidem praefatam regulam absque declaratione aliqua confirmavit, in cuius confirmatione de verbis praedictis mentio aliqua non habetur, ut liquere potest cuilibet confirmationem huiusmodi intuenti: nisi quatenus de vita evangelica habetur mentio in ipsa regula confirmata ibi, quum dicit: Haec est regula fratrum Minorum, videlicet Domini nostri Iesu Christi sanctum evangelium observare, vivendo in obedentia, sine proprio, et in castitate. Ex quibus verbis concludi non potest, quod per ipsum praedecessorem nostrum ea, quae ipsi in verbis praedictis asserunt, fuerint diffinita. Immo potest concludi potius, quod vita evangelica, quam Christus et Apostoli tenuerunt, habere in communi aliqua non excludat, cum sine proprio vivere non exigat, quod sic viventes nihil habeant in communi.

\section{9. (note 42)}

[Nicolaus,] respondens obiectioni tacitae, quae sibi de loculis, quos Christus habuisse in evangelio legitur, poterat fieri, statim quae sequuntur, subiunxit: Nec his quisquam putet obsistere, quod interdum dicitur, Christum loculos habuisse.

\section{0. (note 43)}

Nam sic ipse Christus, cuius perfecta sunt opera, in suis actibus viam perfectionis exercuit, quod interdum, infirmorum imperfectioni condescendens, et viam perfectionis extollerret, et imperfectorum infirmas semitas non damnaret: sic et infirmorum personam Christum asserit in loculis 
suscepisse. Alias impertinens de loculis fuisset obiectio, nisi intellexisset, Christum etiam quoad proprietatem loculos habuisse. Praeterea si diceretur, Christum in loculis habuisse tantumodo simplicem usum facti: frustra diceretur, quod in persona infirmorum ipsos Christus habuit loculos, quum secundum eum perfectis etiam conveniat habere simplicem usum facti. Et, si quaeratur, propter quos infirmos istos loculos habuerit, Augustinus [In epistolam Joannis ad Parthos, X. 62. 5], cuius dictum insertum est in Decretis, respondet, dicens: Habebat Dominus loculos a fidelibus oblata conservans, et suorum necessitatibus, et aliis indigentibus tribuebat.

\section{1. (note 47)}

Dicere siquidem, quod in talibus rebus usus iuris vel facti, separatus a proprietate rei seu dominio, possit constitui, repugnat iuri, et obviat rationi, nec praedecessoris nostri praedicta fuisse intentio fuerit tanti patris, unius ovi, seu casei, aus frusti panis, et aliorum usu consumptibilium, quae saepe fratribus ipsis ad consumendum e vestigio conferuntur, dominium Romane ecclesiae, et usum fratribus retinere?

\section{2. (note 50)}

[...] cum circa res temporales quatuor sit considerare, scilicet proprietatem, possessionem, usumfructum et simplicem usum; et primis quidem vita mortalium possit carere, ultimo vero tanquam necessario egeat.

\section{3. (note 55)}

[...] cum accipitur quod ab illo est imperium, a quo imperator, postquam electus est, examinatur, inungitur, consecratur et coronatur, respondetur quod hoc non continet veritatem, quia nec per examinationem nec per inunctionem nec per consecrationem nec per coronationem potest ostendi quod imperium sit a papa, nec quod imperator sit in temporalibus inferior papa, nec quod a papa debeat confirmari.

\section{4. (note 58)}

Primo igitur quaeritur utrum potestas spiritualis suprema et laicalis suprema ex natura rei in tantum ex opposito distinguatur quod non possint formaliter et simul cadere in eundem hominem. [...] Ergo potestas spiritualis et laicalis contentae sub ea, scilicet potestas spiritualis suprema et laicalis suprema, in tantum distinguuntur ex natura rei quod simul in eodem esse non possunt. [...] potestates illae, quo duo capita corporum diversorum constituunt, simul in eodem esse non possunt, sicut nec idem homo potest simul esse duo capita corporum diversorum. 


\section{5. (note 65)}

Radix autem predicti erroris est, quod imperium est a papa, ut nullus sit verus imperator nec esse possit, nisi qui auctoritatem imperialem et executionem gladii materialis a pontefice romano recepit. Ista autem radix in quadam alia est fundata, quod scilicet papa habet a Christo plenitudinem potestatis, tam in spiritualibus, quam in temporalibus, ut de potentia absoluta omnia possit, quae non sunt contra legem divinam vel legem naturae.

\section{6. (note 68)}

Nam Papa dispensat contra Deum in iuramento et in voto. [...] Papa potest omnia, quae non sunt contra legem Dei nec contra iusa naturae. Praeterea ille habet plenitudinem potestatis, ut omnia possit, cuius sententia sive iusta, sive iniusta est timenda: et eiusdem praeceptum sive iustum, sive iniustum est timendum et servandum.

\section{7. (note 69)}

Illa sententia, sicut dixi, tenet quod papa talem plenitudinem potestatis habet in temporalibus et spiritualibus ut omnia, per potentiam ordinatam vel potentiam absolutam, possit que non sunt contra ius divinum nec contra ius naturale. Non habet regulariter et simpliciter, neque a iure divino neque humano, sed ex ordinatione Christi sive iure divino habet casualiter, sive in casu et secundum quid.

\section{8. (note 70)}

Casualiter tamen, sive in casu, quando scilicet temporalia per alios in periculum communitatis Christianorum vel ad subversionem fidei Christiane tractarentur, vel in casu consimili, converterentur ad malum, et non esset aliquis laicus qui vellet et posset huiusmodi periculis viam precludere, papa a iure divino haberet potestatem faciendi de temporalibus quicquid pro bono communi et salvatione fidei et ad occurrendum huiusmodi periculis necessario faciendum sibi ratio recta dictaret; et ita in tali casu haberet super temporalia, quodammodo et secundum quid, plenitudinem potestatis: non quia tunc temporalia efficerentur sua quoad dominium et proprietatem, nec quod posset ad libitum suum de eis disponere, sed quia nichil potest rex vel alius laicus facere de quacumque re temporali quin tunc idem posset facere papa, si hoc fieri expediret et non esset alius per quem convenienter fieri posset; et ita adhuc in tali casu non haberet plenitudinem potestatis in temporalibus simpliciter, sed tantummodo secundum quid. 


\section{9. (note 71$)$}

Respondeo, et premitto quandam usitatam distinctionem, videlicet quod deum posse hoc vel illud facere potest intelligi dupliciter, scilicet secundum potentiam ordinatam et secundum potentiam absolutam. Non quod in deo sint duae potentiae, una ordinata, alia absoluta-nec hoc volunt significare doctores-sed illud dicitur deus ad intellectum recte intelligentium posse de sua potentia ordinata, quod potest stante sua ordinatione et lege aeterna, quae non est aliud quam eius voluntas, qua eternaliter voluit hac vel illa et taliter vel taliter se facturum; illud autem dicitur posse de potentia absoluta, quod sempliciter et absolute potest. Et econtra illud dicitur non posse secundum potentiam ordinatam, quod non potest stante sua, quae nunc est, ordinatione, illud vero non posse de potentiae absoluta, quod sempliciter et absolute non potest.

\section{0. (note 73)}

Dicendum igitur, cur rerum conditor fabricatorque geniturae omne hoc instituendum putaverit. Optimus erat, ab optimo porro invidia longe relegata est. Itaque consequanter cuncta sui similia, prout cuiusque natura capax beatitudinis esse poterat, effici voluit; quam quidem voluntatem dei originem rerum certissimam si quis ponat, recte eum putare consentiam.

\section{1. (notes 74; 76, and 78)}

1. Circa distinctionem quadragesimam quartam-ubi Magister tractat 'utrum Deus potuit res melius fecisse quam fecit'-quaero istam quaestionem: utrum Deus possit aliter facere res quam ab ipso ordinatum est eas fieri. Et videtur quod non: Quia tunc posset facere res inordinate. Consequens est falsum, ergo et antecedens.

2. Contra: Res aliter fieri quam factae sunt, non includit contradictionem; nec est necessarium; igitur etc.

3. Respondeo: In omni agente per intellectum et voluntatem, potente conformiter agere legi rectae et tamen non necessario conformiter agere legi rectae, est distinguere potentiam ordinatam a potentia absoluta; et ratio huius est, quia potest agere conformiter illi legi rectae, et tunc secundum potentiam ordinatam (ordinata enim est in quantum est principium exsequendi aliqua conformiter legi rectae), et potest agere praeter illam legem vel contra eam, et in hoc est potentia absoluta, excedens potentiam ordinatam. Et ideo non tantum in Deo, sed in omni agente libere-qui potest agere secundum dictamen legis rectae et praeter talem legem vel contra eam-est distinguere inter potentiam ordinatam et absolutam; ideo dicunt iuristae quod aliquis hoc potest facere de facto, hoc 
est de potentia sua absoluta, - - vel de iure, hoc est de potentia ordinata secundum iura. [...]

8. Unde dico quod multa alia potest agere ordinate; et multa alia posse fieri ordinate, $a b$ illis quae fiunt conformiter illis legibus, non includit contradictionem quando rectitudo huiusmodi legis—secundum quam dicitur quis recte et ordinate agere-est in potestate ipsius agentis. Ideo sicut potest aliter agere, ita potest aliam legem rectam statuere,-quae si statueretur a Deo, recta esset, quia nulla lex est recta nisi quatenus a voluntate divina acceptante est statuta; et tunc potentia eius absoluta ad aliquid, non se extendit ad aliud quam ad illud quod ordinate fieret, si fieret: non quidem fieret ordinate secundum istum ordinem, sed fieret ordinate secundum alium ordinem, quem ordinem ita posset voluntas divina statuere sicut potest agere.

\section{2. (note 75$)$}

Deus [...] potest facere hominem cui repugnat peccare. [...] Igitur esset alterius speciei quam fecit, et per consequens Deus potest facere individuum alterius speciei quam fecit, et per consequens mundum alterius speciei, et eadem ratione meliorem.

\section{3. (note 82)}

[...] quia secundum Avicennam I. Metaph. negantes primum principium, sunt verberandi, vel exponendi igni, quousque concedant quod non est idem comburi, et non comburi: vel vapulari, et non vapulare, et ita etiam isti, qui negant aliquod ens contingens, exponendi sunt tormentis, quousque concedant quod possibile est eos non torqueri.

\section{4. (notes 87-88)}

A master says, 'All like things love and unite with one another, and all unlike things shun and hate one another.' Now according to one master no two things are so unlike as heaven and earth. Earth realized that it was by nature alien and unlike to heaven. And so it fled from heaven to the lowest place, and that is why the earth remains motionless, so as not to approach near to heaven. And the celestial nature grew aware that the earth had fled and occupied the lowest place. And that is how the heavens came to empty themselves out in fruitful fashion over th earth, indeed the masters declare that the broad expanse of heaven does not withhold so much as the breadth of a needle point, but brings itself forth totally as fruitfulness on earth. Therefore it is said that the earth is the most fruitful creature among all temporal things. 
I say the same thing about the man who has brought himself to naught in himself and in God and in all creatures: that man has assumed the lowest place, and God is bound to empty Himself totally into him, or He would not be God. I declare in all truth, by the eternal and everlasting truth, that into any man who has abandoned self right down to his ground, God must pour out His whole self in all His might, so utterly that neither of His life, nor His being, nor His nature, nor of His entire Godhead does keep anything back, but must pour out the whole of it as fruitfulness into that man who in abandonment to God has assumed the lowest place.

[...] I have sometimes spoken of a light that is in the soul, which is uncreated and uncreatable. I continually touch on this light in my sermons: it is the light which lays straight hold of God, unveiled and bare, as $\mathrm{He}$ is in Himself, that is, it catches Him in the act of begetting. So I can truly say that this light is far more at one with God than it is with any of the powers with which is subject to hunger or thirst, cold or heat, and that is because being is indivisible. And so, if we consider the powers of the soul in their being, they are all one and equally noble: but if we take them in their functions, one is much higher and nobler than the other.

Therefore I say, if a man turns away from self and from all created things, then - to the extent that you do this-you will attain to oneness and blessedness in your soul's spark, which time and place never touched. This spark is opposed to all creatures: it wants nothing but God, naked, just as He is. It is not justified with the Father or the Son or the Holy Ghost, or all three Persons so far as they preserve their several properties. I declare in truth, this light would not be satisfied with the unity and the whole fertility of the divine nature. In fact I wll say still more, which sounds even stranger: I declare in all truth, by the eternal and everlasting truth, that this light is not content with the simple changeless divine being which neither gives nor takes: rather it seeks to know whence this being comes, it wants to get into its simple ground, into the silent desert into which no distinction ever peeped, of Father, Son or Holy Ghost. In the inmost part, where none is at home, there that light finds satisfaction, and there it is more one than it is in itself, and by this immobility all things are moved, and all those receive life that live of themselves, being endowed with reason.

That we may thus live rationally, may the eternal truth of which I have spoken help us. Amen. 


\section{5. (note 96)}

[...] manifestum est Deum esse omnium complicationem, etiam contradictoriorum, tunc nihil potest eius effugere providentiam; sive enim fecerimus aliquid sive eius oppositum aut nihil, totum in Dei providentia implicitum fuit. Nihil igitur nisi secundum Dei providentiam eveniet.

Unde, quamvis Deus multa potuisset providisse, quae non providit nec providebit, multa etiam providit, quae potuit non providere, tamen nihil addi potest divinae providentiae aut diminui. Ut in simili: Humana natura simplex et una est. Si nasceretur homo, qui etiam numquam nasci exspectabatur, nihil adderetur naturae humanae; sicut nihil demeretur ab illa, si non nasceretur, sicut nec cum nati moriuntur. Et hoc ideo, quia humana natura complicat tam eos qui sunt, quam qui non sunt neque erunt, licet esse potuerunt. Ita licet eveniret, quod numquam eveniet, nihil tamen adderetur providentiae divinae, quoniam ipsa complicat tam ea, quae eveniunt, quam quae non eveniunt, sed evenire possunt. Sicut igitur multa sunt in materia possibiliter, quae numquam evenient, ita per contrarium, quaecumque non evenient, sed evenire possunt, si in Dei sunt providentia, non sunt possibiliter, sed actu; nec inde sequitur, quod ista sint actu. Sicut ergo dicimus, quod humana natura infinita complicat et complectitur, quia non solum homines, qui fuerunt, sunt et erunt, sed qui possunt esse, licet numquam erunt, et ita complectitur mutabilia immutabiliter, sicut unitas infinita omnem numerum: ita Dei providentia infinita complicat tam ea, quae evenient, quam quae non evenient, sed evenire possunt, et contraria, sicut genus complicat contrarias differentias. Et ea, quae scit, non scit cum differentia temporum, quia non scit futura ut futura, nec praeterita ut praeterita, sed aeterne et mutabilia immutabiliter.

Hinc inevitabilis et immutabilis est, et nihil eam excedere potest; et hinc omnia ad ipsam providentiam relata necessitatem habere dicuntur. Et merito, quia omnia in Deo sunt Deus, qui est necessitas absoluta. Et sic patet, quod ea, quae numquam evenient, eo modo sunt in Dei providentia, ut praedictum est, etiam si non sunt provisa, ut eveniant. Et necesse est Deum providisse, quae providit, quia eius providentia est necessaria et immutabilis, licet etiam oppositum eius providere potuit, quod providit. Nam posita complicatione non ponitur res complicata, sed posita explicatione ponitur complicatio. Nam, licet cras possum legere vel non legere, quodcumque fecero, providentiam non evado, quae contraria complectitur. Unde, quidquid fecero, secundum Dei providentiam eveniet. 


\section{6. (note 99)}

Solum igitur absolute maximum est negative infinitum; quare solum illud est id, quod esse potest omni potentia. Universum vero, cum omnia complectatur, quae Deus non sunt, non potest esse negative infinitum, licet sit sine termino et ita privative infinitum; et hac consideratione nec finitum nec infinitum est. Non enim potest esse maius quam est; hoc quidem ex defectu evenit; possibilitas enim sive materia ultra se non extendit. Nam non est aliud dicere 'universum posse semper actu esse maius' quam dicere 'posse esse transire in actum infinitum esse'; quod est impossibile, cum infinita actualitas, quae est absoluta aeternitas, ex posse exoriri nequeat, quae est actu omnis essendi possibilitas. Quare, licet in respectu infinitae Dei potentiae, quae est interminabilis, universum posset esse maius: tamen resistente possibilitate essendi aut materia, quae in infinitum non est actu extendibilis, universum maius esse nequit; et ita interminatum, cum actu maius eo dabile non sit, ad quod terminetur; et sic privative infinitum. Ipsum autem non est actu nisi contracte, ut sit meliori quidem modo, quo suae naturae patitur condicio. Est enim creatura, quae necessario est ab esse divino simpliciter absoluto, prout consequenter in docta ignorantia-quanto clarius et simplicius fieri poterit-quam breviter ostendemus. 